\title{
Ocean productivity south of Australia during spring and summer
}

Michael L. Bender ${ }^{1}$, Bronte Tilbrook ${ }^{2}$, Nicolas Cassar $^{3}$, Bror Jonsson ${ }^{1}$, Alain Poisson ${ }^{4}$, and Thomas W. Trull ${ }^{2}$

Abstract: We estimated mixed layer gross and net community production on a total of 20 crossings in the Australian sector of the Southern Ocean during the summer half-years (October to March) of 2007-2010. These estimates were calculated from measurements of $\mathrm{O}_{2} / \mathrm{Ar}$ ratios and triple isotope compositions of $\mathrm{O}_{2}$ in $\sim 250$ seawater samples collected underway. For comparison purposes, we also measured the seasonal drawdown of mixed layer $\mathrm{NO}_{3}{ }^{-}$and $\mathrm{SiO}_{2}$ concentrations during 2006-2007 and 2007-2008. Across all samples, average values of gross and net $\mathrm{O}_{2}$ production (measured by $\mathrm{O}_{2} / \mathrm{Ar}$ and $\mathrm{O}_{2}$ isotopes), were about $86 \pm 90$ and $18 \pm 17$ $\mathrm{mmol} \mathrm{O}_{2} \mathrm{~m}^{-2}$ day $^{-1}$, respectively. Gross production was highest at the Subtropical Front (up to $\sim 230 \mathrm{mmol} \mathrm{O}_{2} \mathrm{~m}^{-2}$ day $^{-1}$ ), and decreased southward (to $\sim 10$ near the southern boundary of the Antarctic Circumpolar Current). In contrast, net community production showed little meridional variation. Net and gross $\mathrm{O}_{2}$ production increased throughout the spring-to-fall period, although most $\mathrm{SiO}_{2}$ drawdown occurred in December. Consistent with satellite chlorophyll estimates, we saw no evidence for an intense spring bloom (e.g. as has been observed in the North Atlantic). Volumetric net and gross $\mathrm{O}_{2}$ production in the mixed layer, normalized to chlorophyll, increased (with considerable scatter) with average irradiance in the mixed layer. These relationships provide a basis for estimating production from Argo float data and properties observed by satellite.

Affiliations:

1. Department of Geosciences, Princeton University, Princeton, NJ 08544, USA

2. CSIRO Oceans and Atmosphere and Antarctic Climate and Ecosystems Cooperative Research Centre, Hobart, 7001, Australia

3. Division of Earth and Ocean Sciences, Nicholas School of the Environment, Duke University, Durham, NC 27708, USA

4. Laboratoire IMAGES, Université de Perpignan Via Domita, 52 avenue Paul Alduy, 66860 Perpignan Cedex, FranceVia Domitia, France. 


\section{Introduction}

The Southern Ocean has long been identified as the largest High Nutrient Low Chlorophyll

34 (HNLC) region in the global ocean. Variations in its status are important to nutrient delivery to

35 other ocean basins [Sarmiento et al., 2004]. They are also relevant to global carbon sequestration

36 by the biological pump on decadal to at least interglacial timescales [Matear and Hirst, 1999;

37 Sarmiento and Orr, 1991; Sigman and Boyle, 2000]. The High Nutrient appellation is an over-

38 simplification. Phosphate and nitrate remain abundant across the entire Southern Ocean

39 throughout the year. However silica, an essential nutrient for diatoms, which are the dominant

40 large phytoplankton group, becomes depleted in summertime waters between the Subantarctic

41 Front and the Polar Front [Nelson et al., 2001; Treguer and Jacques, 1992; Trull et al., 2001a].

42 Moreover, iron and light are actually the key limiting "nutrients". Lack of iron, an essential

43 element in enzymes, is now known to limit primary production essentially everywhere in the

44 Southern Ocean except near localized sources such as islands, plateaus, and boundary currents

45 [Boyd and Ellwood, 2010]. Low light availability driven by both deep surface mixed layers and

46 cloudiness also limits photosynthesis, including physiological interactions between Fe scarcity

47 and the efficiency of light utilization [Hiscock et al., 2008a; B Greg Mitchell et al., 1991;

48 Strzepek et al., 2012; Sunda and Huntsman, 1997]

49 The Low Chlorophyll status is often linked to these limitations on primary production, but

50 that is also an over-simplification, because loss by grazing and export is at least as strong a

51 control on phytoplankton biomass accumulation [Cullen, 1995; Frost, 1991; F M M Morel et al.,

52 1991; Smith and Lancelot, 2004]. Indeed, despite the LC status, Southern Ocean fluxes of

53 organic carbon to the deep ocean in sinking particles are close to the global median [Honjo et al.,

54 2008; Honjo et al., 2000; Trull et al., 2001c]. The efficiency of this grazing and export may be

55 modulated as mixed layer $\left[\mathrm{SiO}_{2}\right]$ varies seasonally and meridionally.

Improving the understanding of the controls on the HNLC status of the Southern Ocean

57 requires measurements of upper ocean carbon fluxes. In this context, we present a large set of

58 paired estimates of gross primary production (GPP) and net community production (NCP) 
59 derived from gas tracers. The observations cover the north-south extent of Southern Ocean

60 waters and the late spring to early autumn half-year that dominates annual production. As

61 outlined in the Methods section, GPP estimates are based on the isotopic composition of

62 dissolved oxygen, and the NCP estimates are based on the excess of dissolved oxygen

63 concentrations relative to biologically inert argon concentrations. Conversion of these state

64 variables to the GPP and NCP rate variables is achieved by calculation of gas exchange rates

65 with the atmosphere. Both terms reflect productivities averaged over the gas exchange time of

66 the mixed layer (=mixed layer depth/gas transfer velocity) or $\sim 2$ weeks.

67 The results are based on discrete samples collected from the underway clean seawater 68 supply intake onboard the French Antarctic station resupply ship, Astrolabe. Astrolabe made

69 three round-trip crossings of the Southern Ocean each year between Hobart, Tasmania, Australia 70 and Dumont d'Urville, Adelie Land, Antarctica. These crossings made it possible to characterize

71 GPP and NCP six times each season. We can thus evaluate spatial, seasonal, and interannual

72 variations in the rate terms. Using supplementary surface seawater nutrient analyses, Argo float

73 data, and satellite observations, we then can also explore relationships with surface

74 phytoplankton biomass, light levels, and mixed layer depths. Specifically, we focus on three 75 questions:

76 1. Is there a spring phytoplankton bloom seen in primary production (as opposed to 77 biomass accumulation) in the Australian sector of the Southern Ocean, and if so, what are $78 \quad$ its characteristics?

792 2. How does productivity vary with latitude in the Australian sector, and what factors $80 \quad$ mediate this relationship?

81 3. Is there a simple relationship between NCP and GPP and autonomously sensed 82 properties, such as chlorophyll (Chl), sea-surface photosynthetically available radiation 83 (PAR), and mixed layer depth (MLD)? If so, can it be used, in conjunction with ancillary 84 data, to scale local estimates of NCP and GPP to broader regions? 
As expanded on in the Discussion section, our study region south of Australia has the

87 advantage of much background information. Material includes (a) understanding of circulation

88 from six repeats of the WOCE/CLIVAR SR3 hydrographic section from Tasmania to Antarctica

89 [Rintoul and Trull, 2001b; S. Sokolov and Rintoul, 2002; S. Sokolov and Rintoul, 2009; Trull

90 et al., 2001a], (b) special volumes from two month-long process studies of trace element (Fe,

$91 \mathrm{Mn}$, etc.) and macro-nutrient (N, P, Si) biogeochemistry and microbial tropho-dynamics in the

92 SAZ [Bowie et al., 2011a; Bowie et al., 2011b; Bowie et al., 2009; Cassar et al., 2011a; Cassar

93 et al., 2015; Sedwick et al., 2008; Sedwick et al., 1999; Trull et al., 2001b], and (c) an ongoing

94 program, as part of Australia's Integrated Marine Observing System (www.imos.org.au), of air to

95 sea and surface to deep ocean carbon fluxes at the Southern Ocean Time Series site [Rigual-

96 Hernández et al., 2015; Shadwick et al., 2015b; Trull et al., 2001c; Weeding and Trull,

97 2014b]. These efforts provide important context for our observations.

\section{Experimental methods}

\subsection{Principles of the dissolved $\mathrm{O}_{2}$ tracer methods for GPP and NCP}

103 The $\mathrm{O}_{2} /$ Ar ratio of dissolved gases in the mixed layer, and the $\delta^{17} \mathrm{O}$ and $\delta^{18} \mathrm{O}$ of $\mathrm{O}_{2}$, can be

104 used to constrain mixed layer NCP and GPP, respectively [Castro-Morales et al., 2013; Luz and

105 Barkan, 2000; Prokopenko et al., 2011; Reuer et al., 2007]. The $\mathrm{O}_{2} /$ Ar ratio allows physical

106 supersaturation (reflected in both $\mathrm{O}_{2}$ and Ar concentrations) to be removed from the total $\mathrm{O}_{2}$

107 supersaturation. $\mathrm{O}_{2} / \mathrm{Ar}$ measurements thus quantify that part of $\mathrm{O}_{2}$ supersaturation derived from

108 photosynthesis in excess of respiration. Multiplying biological $\mathrm{O}_{2}$ supersaturation by the gas

109 transfer velocity and saturation $\mathrm{O}_{2}$ concentration gives the sea-air flux of biological $\mathrm{O}_{2}$ (termed

110 "net $\mathrm{O}_{2}$ bioflux" or just "net bioflux"). At steady state, and neglecting vertical mixing (see

111 below), this flux must be sustained by photosynthesis in excess of respiration, and hence

112 provides an estimate of NCP. 
113 The estimation of GPP is based on recognition that there are two sources of dissolved $\mathrm{O}_{2}$ in

114 the mixed layer, atmospheric $\mathrm{O}_{2}$, and $\mathrm{O}_{2}$ produced in situ by photosynthesis. Measuring both

$115 \delta^{17} \mathrm{O}$ and $\delta^{18} \mathrm{O}$ of the dissolved $\mathrm{O}_{2}$ constrains the fraction deriving from each of these sources.

116 The tracer quality of the two $\delta$ terms comes from the fact that $\mathrm{O}$ isotopes are mass-dependently

117 fractionated by photosynthesis and respiration (for which the change in $\delta^{17} \mathrm{O}$ is $\sim 0.5$ times the

118 change in $\delta^{18} \mathrm{O}$ ). However, photochemical exchange in the stratosphere leads to non-mass-

119 dependent fractionation, which in turn causes the global atmosphere to be depleted in ${ }^{17} \mathrm{O}$

120 relative to ${ }^{18} \mathrm{O}$ [Luz and Barkan, 2000; Luz et al., 1999]. The relative proportions of atmospheric

121 and photosynthetic $\mathrm{O}_{2}$ in the dissolved $\mathrm{O}_{2}$ pool can be computed from the magnitude of the ${ }^{17} \mathrm{O}$

122 deficiency. Then, from the proportion of photosynthetic $\mathrm{O}_{2}$, the $\mathrm{O}_{2}$ concentration, and the gas

123 transfer velocity, one can calculate the sea-air flux of photosynthetic $\mathrm{O}_{2}$ ("gross bioflux"). At

124 steady-state, and again neglecting vertical mixing, this term provides an estimate of $\mathrm{O}_{2}$ gross

125 primary production.

126 In the text that follows, we generally use the terms NCP and GPP to represent true value of

127 production. We generally use the terms "net $\mathrm{O}_{2}$ bioflux" and "gross $\mathrm{O}_{2}$ bioflux" to represent the

128 sea-air fluxes, calculated from observations, that approximate true net and gross production.

129 The estimates of NCP and GPP from the $\mathrm{O}_{2}$ measurements rely on the assumptions of

130 biological steady-state (constant NCP and GPP) and negligible mixing across the base of the

131 surface mixed layer, as well as the parameterizations of air-sea gas exchange (as detailed below).

132 Probable biases in net $\mathrm{O}_{2}$ bioflux estimates of NCP have been calculated in a model context

133 [Jonsson et al., 2013]. On average, when $\mathrm{O}_{2}$ is biologically supersaturated in the mixed layer, net

$134 \mathrm{O}_{2}$ bioflux underestimates NCP by about $10 \%$. Additional random errors are much larger,

135 probably about $\pm 40 \%$, because of non-steady-state conditions, mixing across the base of the

136 mixed layer, and analytical uncertainties. Experimental studies also show that net and gross

137 bioflux can be influenced by upwelling, vertical mixing, and entrainment (e. g., [Castro-Morales

138 et al., 2013]). We minimize these issues by excluding from our analysis samples that are 
139 undersaturated in $\mathrm{O}_{2}$ (which signifies upwelling). In any case, it is means and trends in our data 140 that are robust, rather than individual excursions.

141 [Nicholson et al., 2014] compared gross bioflux with GPP as simulated in a model

142 context. In their simulations, gross bioflux underestimated GPP in spring. This discrepancy 143 was associated with a modeled spring bloom that is not observed in our data. In summer 144 and autumn, modeled gross bioflux was 2-3 times higher than simulated GPP in the mixed 145 layer. This error derived largely from the entrainment and mixing of deeper euphotic zone 146 waters into the mixed layer, a phenomenon unlikely to be important in our study area. In 147 our data set, MLD was $>40 \mathrm{~m}$ at $88 \%$ of XBT stations, and $>30 \mathrm{~m}$ at $80 \%$ of stations. 148 According to [Westwood et al., 2011], most primary production in the Australian sector 149 occurs above $30 \mathrm{~m}$ depth, and about $90 \%$ above $40 \mathrm{~m}$ depth. Therefore it is improbable 150 that our data is seriously aliased by entrainment and mixing of deeper photosynthetic $\mathrm{O}_{2}$

151 into the mixed layer. There are additional errors associated with lateral advection and non 152 steady-state conditions [Nicholson et al., 2014]. Again, we need to focus on average values 153 and trends rather than individual samples.

\section{$154 \quad 2.2$ Dissolved $\mathrm{O}_{2}$ sample collection and analysis:}

155 The water samples (Fig. 1) were collected from the underway clean seawater supply, which 156 has its intake at about $3 \mathrm{~m}$ depth on the resupply ship Astrolabe. Water samples were collected 157 into pre-evacuated and $\mathrm{HgCl}_{2}$ pre-poisoned $500 \mathrm{ml}$ bottles with Leuwers-Happert O-ring valves, 158 as described by [Emerson et al., 1995] and [Reuer et al., 2007]. The gases equilibrated passively

159 between the water and headspace before analysis in Princeton, and most of the water was

160 removed by aspiration. Non-condensable gases (essentially $\mathrm{O}_{2}, \mathrm{~N}_{2}$, and Ar) were frozen onto 161 molecular sieve and then passed through a gas chromatographic column to separate $\mathrm{O}_{2}$ and $\mathrm{Ar}$ 162 from $\mathrm{N}_{2}$. The $\mathrm{O}_{2}$ and Ar were frozen into a cryo-cooler at $\sim 15^{\circ} \mathrm{K}$, warmed, and admitted to the

163 Finnigan MAT 252 mass spectrometer as described by [Reuer et al., 2007]. ${ }^{18} \mathrm{O}^{16} \mathrm{O},{ }^{17} \mathrm{O}{ }^{16} \mathrm{O}$, and

$164{ }^{16} \mathrm{O}_{2}$ were measured by simultaneous collection for 3 cycles with 24 blocks per cycle. ${ }^{17} \Delta$ of $\mathrm{O}_{2}$ is 165 defined by this equation: 
166

167

168

169

170

171

172

173

174

175

176

177

178

179

180

$$
{ }^{17} \Delta=\ln \left(0.001 \times \delta^{17} \mathrm{O}+1\right)-0.516 \times \ln \left(0.001 \times \delta^{18} \mathrm{O}+1\right)
$$

The uncorrected ${ }^{17} \Delta$ of $\mathrm{O}_{2}$ was computed, using eq. 1 , from the raw data, based only on the observed ion current ratios. A number of factors can affect the raw values of $\delta^{17} \mathrm{O}$ and $\delta^{18} \mathrm{O}$. We evaluated these factors by analyzing the variability of between 76 and 311 air standards measured during each of 5 analysis periods. In total, these extended from February 14, 2006, to January 1,2011 . We rejected all samples where the mass 28 peak was greater than $0.3 \%$ of the mass 32 peak, because high $\mathrm{N}_{2}$ leads to large errors in $\delta^{17} \mathrm{O}$. We observed no dependence of $\delta^{17} \mathrm{O}$ and $\delta^{18} \mathrm{O}$ on the ratio of 28 to 32 ion current for the remaining samples, or on the initial pressure imbalance between sample and reference sides (data not shown). We did not correct for the zero enrichment, which effectively cancels out when seawater is compared with water equilibrated in the laboratory.

The ${ }^{17} \Delta_{\text {raw }}$ values were corrected for differential gas depletion between sample and reference sides during analysis (Stanley et al., 2010), according to the formula:

$$
\text { Imbalance term }=\left(1-\mathrm{V}_{32 \text { sample-end }} / \mathrm{V}_{32} \text { sample }_{\text {sample-start }}\right)-\left(1-\mathrm{V}_{\text {32reference-end }} / \mathrm{V}_{32 \text { reference-start }}\right)(2)
$$

The imbalance term registers the change in the ion current imbalance between sample and reference during 1 block. "V" is the voltage, and the subscripts "end" and "start" refer to the voltages read at the end of the first block by the interfering masses program and that read at the start of the first block by the standard Finnigan ion current acquisition software from which $\delta$ values are calculated.

${ }^{17} \Delta$ data for a large number of equilibrated lab water samples analyzed in this way were higher than the equilibrium value (discussed below) by about $0.005 \%$. We therefore subtracted the average difference, calculated for each of our 5 analysis periods, from the corrected ${ }^{17} \Delta$ value of $\mathrm{O}_{2}$. Knowing ${ }^{17} \Delta$ and $\delta^{18} \mathrm{O}$, we then calculated $\delta^{17} \mathrm{O}$ from equation (1). Because of numerical issues, this approach is marginally more accurate than calculating ${ }^{17} \Delta$ after correcting the measured $\delta^{17} \mathrm{O}$ and $\delta^{18} \mathrm{O}$ values independently. The choice of the coefficient (in equation 1) is 
192 immaterial to the result: we calculate the same $\delta^{17} \mathrm{O}$ value if we use a coefficient of 0.518 . We do

193 not use ${ }^{17} \Delta$ for any other purpose in the analysis of our results.

$194 \delta^{18} \mathrm{O}$ of $\mathrm{O}_{2}$ is fractionated by $0.1-0.3 \%$ during the process of sample preparation. A 195 correction to the measured $\delta^{18} \mathrm{O}$ value is made which does not affect ${ }^{17} \Delta . \mathrm{O}_{2} / \mathrm{Ar}$ ratios were 196 normalized to air and a correction was applied for the residual gas in the water sample after 197 equilibration with the headspace. Uncertainties are $\pm 3 \%$ for the $\mathrm{O}_{2} / \mathrm{Ar}$ ratio, $\pm 0.1 \%$ for $\delta^{18} \mathrm{O}$ of $198 \mathrm{O}_{2}$, and $\pm 0.008 \%$ for ${ }^{17} \Delta$ of $\mathrm{O}_{2}$.

\subsection{Calculation of net and gross production from the $\mathrm{O}_{2}$ tracers}

From $\delta^{17} \mathrm{O}$ and $\delta^{18} \mathrm{O}$ calculated as described above, the ratio of $\mathrm{G} / \mathrm{k}\left[\mathrm{O}_{2}\right]_{\text {eq }}$ is calculated from 204

$\frac{G}{k O_{2}}=\frac{\left(1-\frac{10^{-3} \delta^{17} O_{e q}+1}{10^{-3} \delta^{17} O_{d i s}+1}\right)-\lambda\left(1-\frac{10^{-3} \delta^{18} O_{e q}+1}{10^{-3} \delta^{18} O_{d i s}+1}\right)}{\left(\frac{10^{-3} \delta^{17} O_{p}+1}{10^{-3} \delta^{17} O_{d i s}+1}-1\right)-\lambda\left(\frac{10^{-3} \delta^{18} O_{p}+1}{10^{-3} \delta^{18} O_{d i s}+1}-1\right)} 206$

$209 \mathrm{G}$ is gross $\mathrm{O}_{2}$ production, $\mathrm{k}$ is the gas transfer velocity $\left(\mathrm{m} \mathrm{day}^{-1}\right.$ ), and $\mathrm{O}_{2}$ is the saturation $\mathrm{O}_{2}$

210 concentration. The subscripts " $p$ ", "eq", and "dis" refer to photosynthetic $\mathrm{O}_{2}$, equilibrium $\mathrm{O}_{2}$, and

211 dissolved $\mathrm{O}_{2}$, respectively. $\lambda=0.518$. As shown in this equation, $\mathrm{G} / \mathrm{k}\left[\mathrm{O}_{2}\right]_{\mathrm{eq}}$ is a function of the

212 equilibrium difference between the $\delta^{17} \mathrm{O}$ and $\delta^{18} \mathrm{O}$ of dissolved $\mathrm{O}_{2}$ and that of air $\mathrm{O}_{2}$, the $\delta^{17} \mathrm{O}$ 213 and $\delta^{18} \mathrm{O}$ of dissolved $\mathrm{O}_{2}$ (which we measure), and the $\delta^{17} \mathrm{O}$ and $\delta^{18} \mathrm{O}$ of photosynthetic $\mathrm{O}_{2}$. Air $214 \mathrm{O}_{2}$ is the reference.

$215 \quad \delta^{18} \mathrm{O}_{\mathrm{p}}$ is set at the value for seawater relative to air, -23.320\%o, essentially indistinguishable 216 from the value of $-23.324 \%$ reported by [Barkan and Luz, 2011]. $\delta^{17} \mathrm{O}$ is then set to -

$217 \quad 11.856 \%$. With this assignment, the ${ }^{17} \Delta$ of seawater and photosynthetic $\mathrm{O}_{2}$ with respect to 218 atmospheric $\mathrm{O}_{2}$ is then $+0.249 \%$. These settings invoke the assumption that the $\delta^{17} \mathrm{O}$ and $\delta^{18} \mathrm{O}$ of 
219 photosynthetic $\mathrm{O}_{2}$ is identical to that of the substrate water. We note the discovery that

220 photosynthetic $\mathrm{O}_{2}$ is fractionated inside cells by respiration before it becomes part of the ambient $221 \mathrm{O}_{2}$ pool [Luz and Barkan, 2011]. However, as long as the adopted parameters give a ${ }^{17} \Delta$ value of $222+0.249 \%$ for seawater with respect to air, calculated values of $\mathrm{G} / \mathrm{k}\left[\mathrm{O}_{2}\right]_{\mathrm{eq}}$ will be insensitive to the 223 exact values selected for the isotopic composition of photosynthetic $\mathrm{O}_{2}$.

224 Finally we need to adopt values for $\delta^{17} \mathrm{O}_{\text {eq }}$ and $\delta^{18} \mathrm{O}_{\mathrm{eq}} \cdot \delta^{18} \mathrm{O}_{\mathrm{eq}}$ was accurately measured by 225 as a function of temperature [Benson and Krause, 1980], and we use their temperature226 dependent values. We adopt the ${ }^{17} \Delta$ value for dissolved $\mathrm{O}_{2}$ in equilibrium with air, $+0.008 \%$, 227 measured by [Reuer et al., 2007] and subsequently by [Stanley et al., 2010].

228 Gas transfer velocities between the ocean and atmosphere were calculated as weighted229 average values for the 60 days before collection of the sample, using wind speeds from the 230 NOAA/Seawinds blended product [Chin et al., 1998], and the gas transfer parameterization of 231 [Sweeney et al., 2007]. Gas transfer velocities closer to days of collection were weighted more 232 heavily [Bender et al., 2011; Reuer et al., 2007]. The sea-air biological $\mathrm{O}_{2}$ flux ("net $\mathrm{O}_{2}$ 233 bioflux") was then simply calculated from the product of the biological $\mathrm{O}_{2}$ supersaturation, $\mathrm{O}_{2}$ 234 solubility (i.e. $\mathrm{O}_{2}$ concentration at saturation), and the gas transfer velocity (e. g., [Reuer et al., 235 2007]). Gross $\mathrm{O}_{2}$ bioflux was calculated from the equation of Prokopenko et al. (above).

236 The calculation of net and gross bioflux relies on the assumption that there is negligible 237 addition of air during the collection of the water samples using the ship's underway supply, e.g. 238 from either air forced under the hull by ship motions or exposure to air in the pumping system. 239 The relationship between $\delta^{18} \mathrm{O}$ of $\mathrm{O}_{2}$ and the $\mathrm{O}_{2} / \mathrm{Ar}$ ratio provides an assessment of air injection 240 during collection. In the presence of only biological processes, these two variables are anti241 correlated along a line that passes slightly above the atmospheric equilibrium point (at $\mathrm{O}_{2} / \mathrm{Ar} \sim$ 24286 per mil relative to air, and $\delta^{18} \mathrm{O}$ of $\mathrm{O}_{2}$ about $0.8 \%$, in the Southern Ocean). This occurs 243 because the photosynthetic addition of $\mathrm{O}_{2}$ raises $\mathrm{O}_{2} / \mathrm{Ar}$ while lowering $\delta^{18} \mathrm{O}$ of $\mathrm{O}_{2}$ ( (since 244 photosynthetic $\mathrm{O}_{2}$ has the same $\delta^{18} \mathrm{O}$ as seawater, around -24\%o with respect to air $\mathrm{O}_{2}$, which is 245 the standard). Conversely, respiration consumes $\mathrm{O}_{2}$, lowering $\mathrm{O}_{2} /$ Ar while raising $\delta^{18} \mathrm{O}$ of $\mathrm{O}_{2}$ 
246 (because respiration discriminates against the heavy isotope). The co-occurrence of gas

247 exchange and variable ratios of net/gross production complicates this correlation, but

248 nonetheless, a compact relationship between $\delta^{18} \mathrm{O}$ of $\mathrm{O}_{2}$ and the $\mathrm{O}_{2} / \mathrm{Ar}$ ratio was observed (as

249 shown in Supplementary Material Figure S1). This suggests minimal addition of air to the

250 samples, because air addition changes the $\mathrm{O}_{2} / \mathrm{Ar}$ ratio while leaving $\delta^{18} \mathrm{O}$ nearly unchanged.

251 Based on this diagnostic, visual inspection indicates that less than 5\% of the samples may have

252 experienced significant air injection and only 3 points were sufficiently compromised to require

253 removal from the dataset (Supplementary Material). We also assume that there is negligible

254 removal of $\mathrm{O}_{2}$ as seawater flows through the ship's line from the intake to the sampling space

255 (for a cautionary note see [Juranek et al., 2010]).

256 Finally for this section, we note that either upwelling or net heterotrophy [Hamme et al., 257 2012] can cause net $\mathrm{O}_{2}$ bioflux to be less than zero. We believe that upwelling is by far the 258 dominant cause, for two reasons. First, deep waters, undersaturated in $\mathrm{O}_{2}$, mix to the surface of 259 the Southern Ocean, particularly south of the Polar Front. Second, in the Southern Ocean as 260 elsewhere, there is not enough POC in the mixed layer to sustain net heterotrophy for a large 261 fraction of the summer half-year. We include samples with negative bioflux in our data set 262 (Supplementary Material), but, to keep the focus on productivity controls, we exclude 263 biologically under-saturated samples from the net bioflux values plotted in all other figures. The 264 exception is samples that were biologically undersaturated by $<0.3 \%$ ( $86 \%$ of all samples), 265 which is the analytical uncertainty. In contrast, we include all gross $\mathrm{O}_{2}$ bioflux values in all 266 figures, (regardless of their associated $\mathrm{O}_{2} / \mathrm{Ar}$ values). This is so because gross bioflux is much

267 less affected by upwelling than net bioflux (since the oxygen isotopic gradient across the bottom 268 of the mixed layer is relatively much smaller than the $\mathrm{O}_{2} / \mathrm{Ar}$ gradient). Exchange across the base 269 of the mixed layer also impacts NCP estimates based on nutrient depletions. From model 270 calculations, the bias has been suggested to be up to 2-fold in spring when mixed layer 271 variability is large, and $\sim 10 \%$ in summer when stratification is well established [Wang and 272 Matear, 2001; Wang et al., 2001]. 


\subsection{Additional data sources}

277 Mixed layer macro-nutrient (nitrate, phosphate, and silicic acid) samples were collected in 278 parallel to the oxygen samples (Fig. 2). Nutrient samples were frozen onboard and analyzed in 279 Hobart following WOCE protocols.

280 MLDs used in the interpretation of Astrolabe bioflux data were estimated from XBT's 281 deployed by the ship. The base of the mixed layer was identified using a temperature criterion $282\left(\mathrm{~T}_{\mathrm{z}}\right.$ was $0.2^{\circ} \mathrm{C}$ lower than $\left.\mathrm{T}_{\text {surf }}\right)$ [Montegut et al., 2004].

283 PAR and Chl were characterized by remote sensing [Arrigo et al., 2008], and the extinction 284 coefficient was parameterized in terms of Chl [A Morel and Maritorena, 2001]. Average mixed 285 layer PAR was calculated from the following equation:

286 Average ML PAR = Sea surface PAR * $\int \exp (-\mathrm{kz}) \mathrm{dz} / \mathrm{MLD}$

$287 \mathrm{k}$ is the light attenuation coefficient and $\mathrm{z}$ is depth below the sea surface. The integral is 288 evaluated from the sea surface to the MLD.

289 We also computed chl-normalized net and gross $\mathrm{O}_{2}$ bioflux, dividing bioflux by Chl as 290 inferred from remote sensing. Specifically, we used NASA MODIS/Aqua 2009b daily 4 km level 2913 fields for remotely sensed SST, PAR, and Chl (http://oceancolor.gsfc.nasa.gov). For the 292 purpose of calculating chl-normalized bioflux, the in-situ bioflux observations are matched to 293 nearest available satellite data points, and $\mathrm{Chl}$ is registered for the closest observation within a 1 294 degree radius from the day of collection to 3 days before and after. The inclusion of such 295 potentially distant matches is appropriate as the waters we sample were likely mixed over a large 296 area during the period prior to sampling. We performed sensitivity tests that suggest that the 297 typical maximum error in Chl due to matching of distant locations is less than $\pm 50 \%$, which is 298 within the acceptable range for our application. However, the satellite chlorophyll retrievals add 299 scatter to the calculated values of chl-normalized production. We also note that a number of 
300 papers discuss evidence that Southern Ocean chlorophyll retrievals are aliased toward values

301 lower than in situ measurements [Johnson et al., 2013; Marrari et al., 2006; B. G. Mitchell and

302 Kahru, 2009; Szeto et al., 2011]. This effect may alias our calculations and can be addressed

303 when the Southern Ocean chl algorithm is better constrained.

304 The complete oxygen-based dataset is tabulated in the Supplementary Material.

\section{Results}

We first present contextual observations on the spatial and seasonal variations of water

311 the ARGO and satellite remote sensing estimates of mixed layer depth, insolation, and

312 chlorophyll (section 3.2). We then discuss net and gross bioflux estimates(section 3.3), and

313 examine the relationship between chl-normalized production and mixed layer irradiance.

\subsection{Macro-nutrient drawdown}

$318 \quad\left[\mathrm{NO}_{3}{ }^{-}\right]$and $\left[\mathrm{SiO}_{2}\right]$ are plotted vs. latitude and salinity in Fig. 2 for 2006-2007 and 2007-

319 2008,. The data show the well-known first-order features of Southern Ocean nutrient

320 distributions: increasing concentrations towards higher latitudes (as a result of upwelling), and

321 decreasing concentrations as the growing season progresses (driven by NCP). They also reveal

322 significant interannual variations as well as meridional differences in the stoichiometry of

323 nutrient drawdown. Nitrate concentrations were near zero in Subtropical waters at the very

324 northern end of the transects, and increased strongly across the SAZ to values greater than 20-25

$325 \mu \mathrm{M}$ at the Subantarctic Front. [ $\left[\mathrm{NO}_{3}\right.$-] continued to rise slowly across the PFZ and AZ to reach

326 values of nearly $30 \mu \mathrm{M}$ south of the ACC. In contrast, silicate concentrations were lower over a 
327 much larger portion of the Southern Ocean. $\left[\mathrm{SiO}_{2}\right]$ was $<5 \mu \mathrm{M}$ in both Subtropical and

328 Subantarctic waters. Going southward, we observed both progressive and stepwise $\mathrm{SiO}_{2}$ 329 increases.

330 Fig. 2 shows that the extent and timing of nutrient depletion, as well as Si/N drawdown 331 ratios, varied strongly from zone to zone. In the AZ, where winter Si concentrations were very 332 high, the Si/N drawdown ratio over the season was nearly 10 . In the PFZ, it was closer to 4, and 333 decreased further to $\sim 1$ in the SAZ and to $\sim 0.1-0.2$ in Subtropical waters. High ratios for the $334 \mathrm{Si} / \mathrm{N}$ decrease in the upper water column, such as we find, were previously observed along the 335 nearby WOCE/CLIVAR SR3 north-south hydrographic section [Trull et al., 2001a], and in the 336 AESOPS study south of New Zealand (e. g., [Morrison et al., 2001; Smith Jr et al., 2000]).

337 There are multiple contributing factors to these variations. In the AZ and PFZ, production is 338 dominated by diatoms. Their Si uptake is known to increase with Si availability, and the $\mathrm{Si} / \mathrm{N}$ 339 uptake ratio is expected to be higher under the Fe limited conditions that prevail there [Bowie et 340 al., 2009; Cassar et al., 2011b; Sosik and Olson, 2002]. The uptake ratio under Fe limitation is 341 near 4 vs. near 1 for Fe replete growth, at least for some species [Brzezinski et al., 2002; Franck 342 et al., 2000; Takeda, 1998]. In the SAZ and especially Subtropical waters, non-siliceous 343 organisms contribute significantly to $\mathrm{NCP}$, lowering the $\mathrm{Si} / \mathrm{N}$ drawdown ratio [Kopczynska et al., 344 2001; Trull et al., 2001c]. In addition to these uptake-based controls on Si/N drawdown, 345 remineralization is important. $\mathrm{N}$ is recycled more rapidly than $\mathrm{Si}$, attenuating the ratio of $\mathrm{NO}_{3}{ }^{-}$ $346 / \mathrm{SiO}_{2}$ drawdown [Green and Sambrotto, 2006; Rubin, 2003]. In partial support, there is some 347 evidence for significant nitrification within the surface mixed layer [Fripiat et al., 2015]. N/P 348 drawdown stoichiometry also revealed zonal variations, with the median uptake ratio of N/P 349 ranging from 13-19 in the Subtropical, Subantarctic, and Antarctic zones, but only $\sim 9$ in the 350 PFZ. This result agrees well with [Lourey and Trull, 2001b], who observed a ratio of 15.1 in the 351 SAZ and 8.3 in the PFZ, but the cause remains unclear.

352 Calculation of NCP from the seasonal surface nitrate drawdown is difficult, because vertical 353 distributions were not measured yet appear to be important especially in the PFZ [Lourey and 
354 Trull, 2001a; Parslow et al., 2001]. As well, both vertical mixing and northward Ekman

355 transport provide significant nutrient resupply [DiFiore et al., 2006a; Green and Sambrotto,

356 2006; Rubin, 2003]. Model estimates suggest that these two transport modes double fluxes

357 calculated from springtime nutrient drawdown [Wang and Matear, 2001; Wang et al., 2001].

358 Keeping these caveats in mind, we make approximate first estimates as follows. The seasonal

$359\left[\mathrm{NO}_{3}^{-}\right]$decrease in the Subantarctic Zone was 3-4 $\mu \mathrm{mol} \mathrm{kg}^{-1}$, and about 2-3 $\mu \mathrm{mol} \mathrm{kg}{ }^{-1}$ between

360 the SAF and the SACCF (Fig. 2). For a summer MLD of $\sim 40 \mathrm{~m}$ in the Subantarctic Zone and $~$

$36180 \mathrm{~m}$ to the south, and assuming $\mathrm{C} / \mathrm{N}=7$, then seasonal $\mathrm{NCP}$ would be about $1 \mathrm{~mol} \mathrm{C} \mathrm{m}^{-2}$ across

362 the entire transect from the Subtropical Front to the SACCF. In comparison, depth resolved

363 nitrate estimates suggest $\sim 3-4 \mathrm{~mol} \mathrm{C} \mathrm{m}^{-2}$ for the SAZ from October to March, a period over

364 which mixed depth shoaled from 200 to $\sim 50 \mathrm{~m}$ [DiFiore et al., 2006b; Lourey and Trull, 2001a].

365 There is considerable interannual variability in nutrient drawdown. As an example of

366 interannual variability, October $\mathrm{NO}_{3}{ }^{-}$and $\mathrm{SiO}_{2}$ concentrations were meridionally constant, across

367 the AZ from the Polar Front $\left(\sim 56^{\circ} \mathrm{S}\right)$ south to about $61^{\circ} \mathrm{S}$, in each year of our observations.

368 However, $\left[\mathrm{NO}_{3}^{-}\right]$seasonal drawdown was about $1 \mu \mathrm{M}$ in 2006-7 but closer to $3 \mu \mathrm{M}$ in 2007-8.

369 In this same region, Si was almost fully depleted by January in 2007 but only about half depleted

370 in 2008. The timing of $\mathrm{SiO}_{2}$ depletion in our data set is similar to other observations, which also

371 suggest that the seasonal consumption mainly occurs before the end of January [Green and

372 Sambrotto, 2006; Morrison et al., 2001; Rubin, 2003].

$376 \quad 3.2$ Mixed layer depth, irradiance, and chlorophyll variations

377 In Hovmøller diagrams, Fig. 3 shows weekly estimates for mixed layer depth (MLD), 378 euphotic depth (Z), Chlorophyll concentrations (Chl), and surface photosynthetically available 379 radiation (PAR). Also shown is depth averaged PAR for the mixed layer, and the differences 
380 between the mixed layer and euphotic depths. Also shown are our sparser measurements of net $381 \mathrm{O}_{2}$ bioflux, i.e. estimates of NCP.

382 There are clear seasonal cycles and considerable interannual variability in all these

383 properties. MLD follows the well-known seasonal cycle: deep in winter and shallow in summer, 384 The seasonality is at its largest in the Subantarctic Zone [Rintoul and Trull, 2001b; Rintoul et 385 al., 1997; S. Sokolov, 2008; Trull et al., 2001a]. To generalize from 3 years' data, mixed layers 386 at the beginning of October are $>150 \mathrm{~m}$ deep north of the Polar Front, and shallower to the south.

387 Mixed layers shoal in October in the north and November in the south. In the fall there is a slow 388 transition back to deep wintertime values. Sea surface PAR values track the sun, with maximum 389 values close to summer solstice. Average values of mixed layer PAR have greater variation in 390 seasonal timing. In 2007-2008, mixed layer average PAR in the northern part of the study 391 region was highest before summer solstice. In the next two years it was highest after. This 392 pattern tracks MLD, and is a result of interannual variability in water column stratification.

393 Shallower MLD’s were more prevalent in the early part of the growing season in 2007-

3942008 , and more prevalent in the latter part the following 2 years.

395 In the northern part of the study area, Chl levels rose later in the growing season than the 396 timing of seasonal shoaling of MLD or the increase in mixed layer PAR. In other words, biomass 397 (or at least chlorophyll) continued to increase after stratification. Highest Chl levels were not 398 observed until the end of January, or February. During summer, Chlorophyll concentrations 399 reached a maximum around the Subtropical Front, then decreased towards the south. There was a 400 suggestion that $\mathrm{Chl}$ levels also increased at the southern end of the transect, as Antarctica was 401 approached - a feature that is seen more strongly to the east of the Astrolabe transit in satellite 402 data [S. Sokolov, 2008]). Even the higher Chl accumulations that occurred in the SAZ were not 403 large, rarely reaching more than $1 \mu \mathrm{g} \mathrm{L}^{-1}(3)$. These levels are similar to those reached in the 404 iron-limited sub-arctic North Pacific [Harrison et al., 2004] and can be contrasted with levels 3-5 405 times higher that develop in the more iron-rich [Ryan-Keogh et al., 2013] sub-arctic North 406 Atlantic spring bloom (e.g.[Mahadevan et al., 2012]). 
During the mid-summer periods of highest Chl accumulations, the mixed layer was generally

408 shallower than the euphotic zone (see citations in section 2.1). Vertical mixing would cause our

409 fluxes to overestimate ML production. The effect is strongest north of the subtropical front in

410 summer (Fig. 3), and would cause us to overestimate summertime NCP between $43^{\circ}-46^{\circ}$ south.

411 This effect is unlikely to be important south of the Subtropical Front, where only a small fraction

412 of primary production takes place below the mixed layer (see section 2. 1.).

\subsection{Spatial and temporal distributions of Gross and Net Community Production}

$415 \quad \mathrm{Net}_{2}$ bioflux (as an estimate of NCP) and gross $\mathrm{O}_{2}$ bioflux (as an estimate of GPP) are

416 plotted vs. latitude and averaged over $1^{\circ}$ latitude bands in Fig. 4 (data for all samples are

417 provided in Supplementary Figure S2). In this and subsequent discussions of meridional

418 variations, we exclude from the data set results from the Astrolabe cruise that is to the east of the

419 other cruise tracks (Fig. 1). Net bioflux (averaged over all samples with biological $\mathrm{O}_{2}$

420 supersaturation $>-0.3 \%)$ was $18 \pm 17 \mathrm{mmol} \mathrm{m}^{-2}$ day $^{-1}(1 \sigma, \mathrm{n}=213)$. Gross $\mathrm{O}_{2}$ bioflux was $91 \pm 110$.

421 As discussed above, NCP is likely to be slightly higher than net bioflux, which is aliased low by

422 vertical mixing. The ratio of both average and median net $\mathrm{O}_{2}$ bioflux/gross $\mathrm{O}_{2}$ bioflux was 0.20.

423 These values are all similar to those of other studies of large domains in the Southern Ocean

424 [Green and Sambrotto, 2006; Morrison et al., 2001; Reuer et al., 2007; Rubin, 2003].

425 Gross bioflux was highest from $43-48^{\circ} \mathrm{S}$; in contrast, net bioflux showed no strong

426 meridional trend (Fig. 4). This situation may be compared with that during the autumn SAZ-

427 SENSE voyage (Feb. 2007). During this study, ${ }^{14} \mathrm{C}$ production, gross $\mathrm{O}_{2}$ bioflux, and net $\mathrm{O}_{2}$

428 bioflux were all highest just to the south of the Subtropical Front near $45-46^{\circ} \mathrm{S}$ [Cassar et al.,

429 2011b]. However, it is important to note that the SAZ-SENSE data did not show a monotonic

430 southward decrease of net bioflux. Net bioflux was very low in the southern part of the SAZ,

431 then rose south of the Polar Front. In our Astrolabe data, gross bioflux was highest at the

432 northern end of the transect, but not net $\mathrm{O}_{2}$ bioflux. On the other hand, data from the New 
433 Zealand sector [Reuer et al., 2007] showed a persistent southward decrease in both net and gross

434 bioflux from November or December through February.

435 Monthly average values (and standard errors) for gross and net bioflux are plotted vs.

436 Southern Ocean Zone, from STZ to SACC, in Fig. 5. These data again illustrate the main

437 temporal and meridional trends. There is a southward decrease in gross bioflux but little or no

438 decrease in net bioflux. Maximum values of net bioflux come after the New Year. South of the

439 Subrtopical Front, maximum values of both net and gross bioflux occur in January. This feature

440 may be linked to the rapid drawdown of $\mathrm{SiO}_{2}$ in the December-January period.

441 The maintenance of high gross production into the beginning of March may be associated

442 with elevated chlorophyll and shallow mixed layer depths during this time (Fig. 3). Iron is likely

443 decreasing throughout the growing season [Bowie et al., 2009; Sedwick et al., 2008], but light

444 and chlorophyll apparently win in our domain.

445 For the period from October to the beginning of March ( $\sim 130$ days), net $\mathrm{O}_{2}$ bioflux averaged

44617,18 , and $17 \mathrm{mmol} \mathrm{m}^{-2}$ day $^{-1}$ for the Subtropical Zone, Subantarctic Zone, and Polar Front zone

447 respectively. For a growing season of 130 days and $\Delta \mathrm{CO}_{2} / \Delta \mathrm{O}_{2}=117 / 170$ (Sarmiento and

448 Anderson, 1994), NCP inferred from our $\mathrm{O}_{2} / \mathrm{Ar}$ data would be $1.5 \mathrm{~mol} \mathrm{C} \mathrm{m}^{-2}$ year $^{-1}$. Thus our

449 estimates are in reasonably good agreement with values estimates from a detailed seasonal cycle

450 study at $46^{\circ} 56^{\prime} \mathrm{S}, 142^{\circ} 15^{\prime} \mathrm{E}$ using hourly autonomous moored observations of $\mathrm{O}_{2}$ and $\mathrm{pCO}_{2}$

451 ( 2 mol C m${ }^{-2}$ ) [Shadwick et al., 2015a; Weeding and Trull, 2014b]). Estimates from $\mathrm{NO}_{3}{ }^{-}$

452 drawdown are similar (section 3.2). As with the Chl abundances, our NCP estimates are

453 relatively low overall $\left(<20 \mathrm{mmol} \mathrm{m}^{-2}\right.$ day $\left.^{-1}\right)$. These values are similar to sub-Arctic North Pacific

454 waters (e.g. [Harrison et al., 2004]). They are about an order of magnitude below NCP values

455 during the spring bloom in the sub-Arctic North Atlantic [Alkire et al., 2012; Bender et al.,

456 1992; Quay et al., 2012]. There, NCP can be as high as 1 mole $\mathrm{C} \mathrm{m}^{-2}$ over a period of order 1

457 week, equivalent to net $\mathrm{O}_{2}$ bioflux values of about $200 \mathrm{mmol} \mathrm{m}^{-2}$ day $^{-1}$.

458 The seasonal cycle of NCP inferred here for the Subantarctic Zone is very different from

459 that of [Weeding and Trull, 2014a], who measured $\left[\mathrm{O}_{2}\right]$ and gas tension using a mooring. 
460 They diagnosed very high values of $\mathrm{O}_{2} \mathrm{NCP}$ in early spring. These high values were required

461 to explain the observed time series of [ $\left.\mathrm{O}_{2}\right]$, given evidence for rapid entrainment from deep

462 mixed layers and highly variable mixed layer depths. This entrainment kept $\mathrm{O}_{2}$

463 undersaturated at the surface until the middle of December, after which time vertical

464 mixing has little influence on the $\mathrm{O}_{2}$ balance of the mixed layer (their Fig. $5 \mathrm{C}$ ). In contrast,

465 the mixed layer was generally supersaturated in biological $\mathrm{O}_{2}$ during our cruises (Table S-

466 1). Also, we calculated NCP only for waters that were biologically supersaturated in $\mathrm{O}_{2}$.

467 Thus biases from entrainment in our observations are likely to be small.

468 The difference between the two studies may also reflect spatial variations in the depth 469 and intensity of late winter and early spring deep convection south of Australia., The 470 Southern Ocean Time Series site southwest of Tasmania studied by Weeding and Trull $471\{2014 \mathrm{~b}]$ exhibits deeper winter mixed layers than along the our Astrolabe transects and 472 the nearby WOCE/Clivar SR3 line [Dong et al., 2008; Rintoul and Bullister, 1999; Rintoul and 473 Trull, 2001a]. Interannual variability may also contribute to the difference. We observed 474 biological supersaturation in the spring of 2007 and 2008, but mixed saturation status in 475 spring, 2009. Significant interannual variability in biological $\mathrm{O}_{2}$ supersaturation and net $\mathrm{O}_{2}$

476 bioflux is hardly surprising given the large difference in Subantarctic Zone nitrate 477 concentrations in October and November, 2006, relative to 2007. Spatio-temporal 478 variations may also explain high NCP inferred from nutrient and carbon dioxide 479 observations in Drake Passage in springtime [Munro et al., 2015]. Overall, these other 480 observations of high springtime NCP do not invalidate our conclusion that, in $\mathrm{O}_{2}$ 481 supersaturated waters south of Australia, springtime productivity is not particularly high.

\section{4. Discussion}

\section{$483 \quad 4.1$ Relationships between Chl, mixed layer PAR, and gross and net bioflux}

484 The relationship between sea surface PAR, MLD, and production has been at the heart of 485 attempts to understand seasonal and spatial variability in productivity back to at least the classic 486 paper of [Sverdrup, 1953]. It is also at the center of algorithms to calculate ${ }^{14} \mathrm{C}$ production from 
487 remotely observed properties of the sea surface (e. g., [Behrenfeld and Falkowski, 1997]). Here

488 we analyze the relationship between these properties using a simple approach that has basic

489 mechanistic content. Our objectives are to identify a simple and transparent relationship between

490 these properties, and to advance the possibility of simulating NCP from remotely sensed

491 properties and Argo/BioARGO float data.

492 Specifically, we focus on the relationship between average volumetric production in the

493 mixed layer normalized to $\mathrm{Chl}$, and average irradiance in the mixed layer. One expects these

494 terms to be related, because productivity increases as irradiance rises and as Chl rises. Our work

495 follows, for example, the Vertically-Generalized Productivity Model of [Behrenfeld and

496 Falkowski, 1997]. Upon rearranging Eq. (10) of their paper, one gets an equation stating that the

497 rate of Chl-normalized volumetric primary production in the euphotic zone scales with

498 irradiance. Their irradiance term takes into account light saturation, and their model is more

499 process- rich than ours (therefore also more complex), but the basic premises are similar.

$500 \quad$ In our model, the relevant terms are calculated as follows:

501 Chl-normalized volumetric gross bioflux in the $\mathrm{ML}=$ gross $\mathrm{O}_{2}$ bioflux / (MLD*Chl) (5)

502 Chl-normalized volumetric net bioflux in the $\mathrm{ML}=$ net $\mathrm{O}_{2}$ bioflux / (MLD* Chl)

503 The equation for calculating average ML irradiance was presented earlier. Chl is in $\mathrm{mg} \mathrm{m}^{-3}$.

504 The units of volumetric bioflux are $\mathrm{mmol} \mathrm{O}_{2} \mathrm{mg} \mathrm{Chl}^{-1}$ day $^{-1}$. Average ML irradiance has the 505 units of photons $\mathrm{m}^{-2}$ day $^{-1}$.

506 In evaluating the relationship between normalized bioflux and average ML irradiance, we 507 exclude all samples with $\mathrm{Chl}<0.10 \mathrm{mg} \mathrm{m}^{-3}$, because at these low levels Chl retrieved from space 508 may have large uncertainties (e. g., [Johnson et al., 2013]). As outlined above, we exclude 509 samples from the net bioflux analysis that were biologically undersaturated in $\mathrm{O}_{2}$ by $>0.3 \%$. We 510 also exclude two measurements of gross bioflux that were extreme outliers. We then plot 511 normalized gross $\mathrm{O}_{2}$ bioflux and normalized net $\mathrm{O}_{2}$ bioflux vs. average ML irradiance (Fig. 6).

512 Chl-normalized volumetric gross and net $\mathrm{O}_{2}$ bioflux both rise with increasing values of 513 average ML irradiance, albeit with continuous scatter. Out to a light flux of $\sim 25 \mathrm{~mol} \mathrm{~m}^{-2}$ day $^{-1}$, 
514 there is no strong indication that irradiance is saturating. The $\mathrm{R}^{2}$ is 0.44 for both normalized net

515 bioflux and normalized gross bioflux plotted vs. average ML irradiance. This level of shared

516 variance is remarkably high given errors in derived properties (satellite Chl observations, gas

517 transfer velocity, mixed layer PAR, light attenuation coefficient) and the simplistic nature of the

518 assumptions for calculating $\mathrm{O}_{2}$ bioflux (steady state, no water flux across the base of the mixed 519 layer).

520 We analyzed the apparent absence of light saturation in the plots of normalized production 521 vs. average ML irradiance using a simple model based on curves of 1 -hour ${ }^{14} \mathrm{C}$ production vs. 522 irradiance [Westwood et al., 2011] on the SAZ-SENSE cruise. According to Westwood et al., 523 saturating irradiance during the SAZ-SENSE cruise averaged $56 \mu \mathrm{mol}$ photons $\mathrm{m}^{-2} \mathrm{sec}^{-1}$ when 524 evaluated for those stations where the MLD was within the euphotic zone. For a 16-hour day, 525 this number corresponds to about 3 mol photons $\mathrm{m}^{-2}$ day $^{-1}$. It is approximately equal to the 526 median value of average daily ML irradiance for our samples (Fig. 6). However, Fig. 6 shows 527 that gross and net $\mathrm{O}_{2}$ bioflux continue to increase at higher irradiances, despite the fact that 528 average daily ML irradiance is saturating. There are 2 reasons. First, light decreases 529 exponentially with depth. Therefore, most of the mixed layer lies below the depth of average ML 530 irradiance. Second, irradiance will be low, and production will be light-limited, towards the 531 beginning and end of the photoperiod. For these 2 reasons, production during the photoperiod 532 may be light-limited even if average irradiance in the mixed layer exceeds the light-saturated 533 value.

$534 \quad$ In Fig. 7, we quantify these effects by plotting relative $\mathrm{O}_{2}$ production vs. irradiance for the 535 case where saturating irradiance $=56 \mu \mathrm{mol}$ photons $\mathrm{m}^{-2} \mathrm{sec}^{-1}$. We assume that instantaneous 536 production increases linearly with irradiance until it reaches the saturation value (at $56 \mu \mathrm{mol}$ 537 photons $\mathrm{m}^{-2} \mathrm{sec}^{-1}$ ), and is constant thereafter. In our calculation, insolation decreases 538 symmetrically about the noontime value along a hyperbolic curve that goes to zero at $4 \mathrm{AM}$ and $5398 \mathrm{PM}$ (i.e., $16 \mathrm{~h} / 8 \mathrm{~h}$ light/dark cycle). We calculate relative ML production for MLD from 1-100 $540 \mathrm{~m}$, in $1 \mathrm{~m}$ intervals. Corresponding values of average ML irradiance decrease from 45 to $6 \mu \mathrm{mol}$ 
$541 \mathrm{~m}^{-2} \mathrm{sec}^{-1}$. Mixed layer $\mathrm{O}_{2}$ production saturates at an average irradiance of $\sim 15 \mathrm{~mol}$ photons $\mathrm{m}^{-2}$

542 day $^{-1}$, approaching the highest value observed for our samples. Hence most of the mixed layer is

543 light-limited for most of the day, and we expect that gross $\mathrm{O}_{2}$ production will increase with

544 increasing irradiance, given the ambient range of ML irradiances. In practice, of course,

545 production must eventually saturate at high irradiance. This dependence may be present in the

546 curve of normalized gross $\mathrm{O}_{2}$ evolution (Fig. 7, left), but there is a lot of scatter.

547 Various factors complicate the relationship between light, $\mathrm{Chl}$, and $\mathrm{O}_{2}$ production is the iron

548 sufficiency of the ecosystem, which also influences $\mu$. There are ample data suggesting that iron

549 sufficiency changes in the study region (e. g., [Cassar et al., 2011b]). [Hiscock et al., 2008b]

550 argued that the effect of iron on the physiology of individual phytoplankton is to increase the

551 initial slope of the P-I curve while leaving light-saturated production unchanged. In their

552 experiments, the slope varied by about a factor of 2 between Fe-limited and Fe-sufficient

553 phytoplankton. This variability would lead to scatter in the curve of gross $\mathrm{O}_{2}$ production (or

554 bioflux) vs. average ML irradiance, but the basic relationship would be unchanged. In fact the

555 greatest relevant effect of $\mathrm{Fe}$ is simply to cause a rise in the Chl. We implicitly acknowledge this

556 effect by normalizing to Chl. Other obvious confounding factors include water temperature, light

557 acclimation, and the changing nature of Southern Ocean ecosystems.

558 Despite these complications, our results show that there is a strong relationship between

559 volumetric net and gross bioflux normalized to Chl, and average ML irradiance. These

560 relationships can be exploited, using remotely sensed Chl values and MLD's from ARGO floats

561 and other sources, to scale local estimates of GPP and NCP to broader areas of the Southern

562 Ocean. Scaled values can be used to achieve a better understanding of process-level controls on

563 production, and to improve the simulation of biogeochemical cycles in models. 
$5674.2 \quad$ Net/gross bioflux variationsThere are many possible controls on the overall trend of 568 lower NCP/GPP ratios in the northern regions of the Southern Ocean observed here (Figure 4).

569 For example, zooplankton grazing and remineralization are both more effective in warmer waters

570 [Laws et al., 2000; Steinberg et al., 2008]. In addition, lower levels of $\mathrm{SiO}_{2}$ in the north may

571 limit the growth of diatom micro-plankton, whose size allows them to more readily escape

572 grazing pressure [Assmy et al., 2013; F M M Morel et al., 1991]. Importantly, the complexity of

573 tropho-dynamics means that high NCP can still occur in small phytoplankton communities, as

574 has been observed previously in this region [Cassar et al., 2015], including contributions to

575 carbon export to the ocean interior [Richardson and Jackson, 2007].

\section{Conclusions}

Our data allow us to answer our three key research questions, outlined in the Introduction, as 581 follows:

582 1. In the Australian sector of the Southern Ocean there is no evidence of a spring bloom in 583 the sense of very high rates of photosynthesis and carbon export.

5842 2. The oxygen based GPP and NCP estimates (and the $\mathrm{SiO}_{2}$ and $\mathrm{NO}_{3}^{-}$drawdowns) show considerable latitudinal and year to year variability, but with an overall trend of higher GPP in the north and little latitudinal variation in NCP.

3. Chl-normalized values of net and gross $\mathrm{O}_{2}$ bioflux scale with average mixed layer irradiance, albeit with a high level of scatter. This relationship provides a useful check on models of productivity based on remote sensing, that can be evaluated further in future studies. The relationship also provides a basis for scaling GPP and NCP in the Southern Ocean based on Chl observed from satellites and mixed layer depths from ARGO floats 
Acknowledgements:

Sampling on Astrolabe was supported by a French-Australian research collaboration and

600 Polaire Francais are thanked for allowing access to the ship and for help with field operations, as

601 is the assistance provided by Drs. C. Goyet and N. Metzl. The Australian Climate Change

602 Research Program, Antarctic Climate and Ecosystems Co-operative Research Centre, and the

603 Integrated Marine Observing System funded the collection of water samples and nutrient

604 analyses, and the operation of underway sensors reported in this study. Bender, Cassar, and

605 Jonsson gratefully acknowledge financial support from NASA and the Office of Polar Programs,

606 NSF. Alan Poole and Matt Sherlock from CSIRO were frequently called on to ensure equipment

607 functioned for the voyages.

608

609 
$610 \quad$ References

611

612 Alkire, M. B., et al. (2012), Estimates of net community production and export using high-

613 resolution, Lagrangian measurements of 02, NO3-, and POC through the evolution of a

614 spring diatom bloom in the North Atlantic, Deep-Sea Research I, 64, 157-174.

615 Assmy, P., V. Smetacek, M. Montresor, C. Klaas, J. Henjes, V. H. Strass, J. M. Arrieta, U.

616 Bathmann, G. M. Berg, and E. Breitbarth (2013), Thick-shelled, grazer-protected

617 diatoms decouple ocean carbon and silicon cycles in the iron-limited Antarctic

618 Circumpolar Current, Proceedings of the National Academy of Sciences, 110(51), 20633-

61920638.

620 Behrenfeld, M. J., and P. G. Falkowski (1997), Photosynthetic rates derived from satellite-

621 based chlorophyll concentration, Limnology and Oceanography, 42, 1-20.

622 Bender, M. L., S. Kinter, N. Cassar, and R. Wanninkhof (2011), Evaluating gas transfer

623 parameterizations using upper ocean radon distributions, Journal of Geophysical

624 Research, 116, doi: 10.1029/2009JC0058-1025.

625 Bender, M. L., H. Ducklow, J. Kiddon, J. Marra, and J. Martin (1992), The carbon balance

626 during the 1989 spring bloom in the NOrth Atlantic Ocean, $47^{\circ} \mathrm{N}, 20^{\circ} \mathrm{W}$, Deep-Sea

627 Research Part A, 39, 1707-1725.

628 Bowie, A. R., T. W. Trull, and F. Dehairs (2011a), Estimating the Sensitivity of the

629 Subantarctic Zone to Environmental Change: the SAZ-Sense project., Deep Sea Research

$630 \quad I I, 58(21-22), 2051-2058$.

631 Bowie, A. R., F. B. Griffiths, F. Dehairs, and T. W. Trull (2011b), Oceanography of the

632 subantarctic and Polar Frontal Zones south of Australia during summer: Setting for the

633 SAZ-Sense study, Deep-Sea Research II, 58(21-22), 2059-2070.

634 Bowie, A. R., D. Lannuzel, T. A. Remenyi, T. Wagener, P. J. Lam, P. W. Boyd, C. Guieu, A. T.

635 Townsend, and T. W. Trull (2009), Biogeochemical iron budgets of the Southern Ocean 
636 south of Australia: Decoupling of iron and nutrient cycles in the subantarctic zone by 637 the summertime supply, Global Biogeochemical Cycles, 23.

638 Boyd, P. W., and M. J. Ellwood (2010), The biogeochemical cycle of iron in the ocean, Nature $639 \quad$ Geoscience, 3, $675-682$.

640 Brzezinski, M. A., C. J. Pride, V. M. Franck, D. M. Sigman, J. L. Sarmiento, K. Matsumoto, N.

641 Gruber, G. H. Rau, and K. H. Coale (2002), A switch from Si(OH)4 to NO3- depletion in 642 the glacial Southern Ocean, Geophysical Research Letters, 29(12), 5-1-5-4.

643 Cassar, N., P. DiFiore, B. A. Barnett, M. L. Bender, A. R. Bowie, B. Tilbrook, K. Petrou, K.

644 Westwood, S. Wright, and T. Wagener (2011a), The influence of iron and light on net 645 community production in the Subantarctic and Polar Frontal Zones, Biogeosciences, 7, $646 \quad 5649-5674$.

647 Cassar, N., P. J. DiFiore, B. A. Barnett, M. L. Bender, A. R. Bowie, B. Tilbrook, K. Petrou, K. J. 648 Westwood, S. W. Wright, and D. Lefevre (2011b), The influence of iron and light on net 649 community production in the Subantarctic and Polar Frontal Zones, Biogeosciences, 8 , $650 \quad 227-237$.

651 Cassar, N., et al. (2015), The relation of mixed-layer carbon export production to plankton 652 community in the Southern Ocean, Global Biogeochemical Cycles, .

653 Castro-Morales, K., N. Cassar, D. R. Shoosmith, and J. Kaiser (2013), Biological production in 654 the Bellingshausen Sea from oxygen-to-argon ratios and oxygen triple isotopes, 655 Biogeosciences, 10, 2273-2291.

656 Chin, T. M., R. F. Milliff, and W. G. Large (1998), Basin-scale, high-wavenumber sea surface 657 wind fields from a multireolsuion analysis of scatterometer data, Journal of Atmospheric 658 and Oceanic Technology, 15, 741-763.

659 Cullen, J. J. (1995), Status of the iron hypothesis after the Open-Ocean Enrichment 660 Experiment, Limnology and Oceanography, 40(7), 1336-1343. 
661 DiFiore, P. J., D. M. Sigman, T. W. Trull, M. J. Lourey, K. Karsh, G. Cane, and R. Ho (2006a),

662 Nitrogen isotope constraints on subantarctic biogeochemistry, Journal of Geophysical 663 Research, 111, doi 10.1029/2005JC003216.

664 DiFiore, P. J., D. M. Sigman, T. W. Trull, M. J. Lourey, K. Karsh, G. Cane, and R. Ho (2006b), 665 Nitrogen isotope constraints on Subantarctic biogeochemistry, Journal of Geophysical 666 Research, 111, C08016, doi:08010.01029/02005JC003216.

667 Dong, S., J. Sprintall, S. T. Gille, and L. Talley (2008), Southern Ocean mixed layer depth from 668 Argo float profiles, Journal of Geophysical Research-Oceans, 113, 2008.

669 Franck, V. M., M. A. Brzezinski, K. H. Coale, and D. M. Nelson (2000), Iron and silicic acid 670 concentrations regulate Si uptake north and south of the Polar Frontal Zone in the 671 Pacific Sector of the Southern Ocean, Deep-Sea Research Part II, 47, 3315-3338.

672 Fripiat, F., et al. (2015), Enhanced nitrification in a natural iron-fertilized bloom of the 673 Southern Ocean, Global Biogeochemical Cycles, in review.

674 Frost, B. (1991), The role of grazing in nutrient-rich areas of the open sea, Limnology and $675 \quad$ Oceanography, $36,1834-1850$.

676 Green, S. E., and R. N. Sambrotto (2006), Net community production in terms of C, N, P and 677 Si in the Antarctic Circumpolar Current and its influence on regional water mass 678 characteristics, Deep-Sea Research Part I, 53, 111-135.

679 Hamme, R. C., et al. (2012), Dissolved 02/Ar and other methods reveal rapid changes in 680 productivity during a Lagrangian experiment in the Southern Ocen, Journal of $681 \quad$ Geophysical Research Oceans, 117, doi: 10.1029/2011JC007046.

682 Harrison, P. J., F. A. Whitney, A. Tsuda, H. Saito, and K. Todokoro (2004), Nutrient and 683 plankton dynamics in the NE and NW gyres of the Subarctic Pacific Ocean, Journal of 684 Oceanography, 60, 93-117.

685 Hiscock, M. R., V. P. Lance, A. M. Apprill, R. R. Bidigare, Z. I. Johnson, B. G. Mitchell, W. 0. 686 Smith, and R. T. Barber (2008a), Photosynthetic maximum quantum yield increases are 
an essential component of the Southern Ocean phytoplankton response to iron, Proceedings of the National Academy of Sciences, 105(12), 4775-4780.

Hiscock, M. R., V. P. Lance, A. M. Apprill, R. R. Bidigare, Z. I. Johnson, B. G. Mitchell, W. O.

Smith, and R. T. Barber (2008b), Photosynthetic maximum quantum yield increases are an essential component of the South Ocean phytoplankton response to iron, Procedings of the National Academy of Sciences, 105, 4775-4780.

Honjo, S., S. J. Manganini, R. A. Krishfield, and R. Francois (2008), Particulate organic carbon fluxes to the ocean interior and factors controlling the biological pump: A synthesis of global sediment trap programs since 1983, Progress in Oceanography, 217-285, 217285.

Honjo, S., R. Francois, S. Manganini, J. Dymond, and R. Collier (2000), Particle fluxes to the interior of the Southern Ocean in the Western Pacific sector along 170。W, Deep-Sea Research II, 47(15-16), 3521-3548.

Johnson, R., P. G. Strutton, S. W. Wright, A. McMinn, and K. M. Meiners (2013), Three improved satellite chlorophyll algorithms for the Southern Ocean, Journal of Geophysical Research: Oceans, 118(7), 3694-3703.

Jonsson, B. F., S. C. Doney, J. Dunne, and M. Bender (2013), Evaluation of the Southern Ocean 02/Ar-based NCP estimates in a model framework, Journal of Geophysical Research: Biogeosciences, 118(2), 385-399.

Juranek, L. W., R. C. Hamme, J. Kaiser, R. Wanninkhof, and P. D. Quay (2010), Evidence of 02 consumption in underway seawater lines: IMplications for air-sea 02 fluxes, Geophysical Research Letters, 37, DOI: 10.1029/2009GL04023.

Kopczynska, E. E., F. Dehairs, M. Elskens, and S. Wright (2001), Phytoplankton and microzooplankton variability between the Subtropical and Polar Fronts south of Australia (SAZ' 98): thriving under regenerative and new production in late summer, Journal of Geophysical Research, 106(C12), 31,597-531,609. 
713 Laws, E. A., P. G. Falkowski, W. O. J. Smith, H. Ducklow, and J. J. McCarthy (2000),

714 Temperature effects on export production in the open ocean, Global Biogeochemical $715 \quad$ Cycles, 14(4), 1231-1246.

716 Lourey, M. J., and T. W. Trull (2001a), Seasonal nutrient depletion and carbon export in the

717 Subantarctic and Polar Frontal Zones of the Southern Ocean south of Australia, Journal 718 of Geophysical Research-Oceans, 106(C12), 31463-31487.

719 Lourey, M. J., and T. W. Trull (2001b), Seasonal nutrient depletion and carbon export in the

720 Subantarctic and Polar Frontal Zones of the Southern Ocean south of Australia, Journal 721 of Geophysical Research, 106, 31463-31487.

722 Luz, B., and E. Barkan (2000), Assessment of oceanic productivity with the triple-isotope 723 composition of dissolved oxygen, Science, 288(5473), 2028-2031.

724 Luz, B., E. Barkan, M. L. Bender, M. H. Thiemens, and K. A. Boering (1999), Triple-isotope

725 composition of atmospheric oxygen as a tracer of biosphere productivity, Nature, $726 \quad 400(6744), 547-550$.

727 Mahadevan, A., E. D'Asaro, C. Lee, and M. J. Perry (2012), Eddy-driven stratification initiates $728 \quad$ North Atlantic spring phytoplankton blooms, Science, 54, 54-58.

729 Marrari, M., c. Hu, and K. Daly (2006), Validation of SeaWiFS chlorophyll a concentrations in 730 the Southern Ocean: A revisit, Remote Sensing of the Environment, 105, 367-376.

731 Matear, R., and A. C. Hirst (1999), Climate change feedback on the future oceanic CO2 732 uptake, Tellus, 51(3), 722-733.

733 Mitchell, B. G., and M. Kahru (2009), Bio-Optical algorithmes for ADEOS-2 GLI, Journal of the 734 Remote Sensing Society of Japan, 29, 80-85.

735 Mitchell, B. G., E. A. Brody, O. Holm-Hansen, C. McClain, and J. Bishop (1991), Light

736 limitation of phytoplankton biomass and macronutrient utilization in the Southern 737 Ocean, Limnology and Oceanography, 36(8), 1662-1677. 
738 Montegut, C., G. Madec, A. S. Fischer, A. Lazar, and D. Iudicone (2004), Mixed layer depth

739 over the global ocean: An examination of profile data and a profile-based climatology,

$740 \quad$ Journal of Geophysical Research, 109, doi: 10.1029/2004JC002378.

741 Morel, A., and S. Maritorena (2001), Bio-optical properties of oceanic waters: A reappraisal, 742 Journal of Geophysical Research: Oceans, 106, 7163-7180.

743 Morel, F. M. M., J. G. Reuter, and N. M. Price (1991), Iron nutrition of phytoplankton and its

744 possible importance in the ecology of ocean regions with high nutrient and low

745 biomass, Oceanography, 4, 56-61.

746 Morrison, J. M., S. Gaurin, L. A. Codispoti, T. Takahashi, F. J. Millero, W. D. Gardner, and M. J.

747 Richardson (2001), Seasonal evolution of hydrographic properties in the Antarctic

748 circumpolar current at 170 W during 1997-1998, Deep-Sea Research Part II, 48, 3943-

$749 \quad 3972$.

750 Munro, D. R., N. S. Lovenduski, B. B. Stephens, T. Newberger, K. R. Arrigo, T. Takahashi, P. D.

751 Quay, J. Sprintall, N. M. Feeman, and C. Sweeney (2015), Estimates of net community

752 production in the Southern Ocean determined from time series observations (2002-

753 2011) of nutrients, dissolved inorganic carbon, and surface ocean pCO2 in Drake

754 Passage, Deep-Sea Research II, 114, 49-63.

755 Nelson, D. M., M. A. Brzezinski, D. E. Sigmon, and V. M. Frank (2001), A seasonal progression

756 of Si limitation in the Pacific sector of the Southern Ocean, Deep-Sea Research II, 48,

$757 \quad 3973-3995$.

758 Nicholson, D., H. R. H. Stanley, and S. C. Doney (2014), The triple oxygen isotope tracer of

759 primary productivity in a dynamic ocean model, Global Biogeochemical Cycles, 28, 538-

$760 \quad 552$.

761 Parslow, J., P. Boyd, S. R. Rintoul, and F. B. Griffiths (2001), A persistent sub-surface

762 chlorophyll maximum in the Polar Frontal Zone south of Australia: seasonal

763 progression and implications for phytoplankton-light-nutrient interactions, Journal of

$764 \quad$ Geophysical Research, 106, 31543-31557. 
765 Prokopenko, M. G., O. M. Pauluis, J. Granger, and L. Y. Yeung (2011), Exact evaluation of

766 gross photosynthetic production from the oxygen triple-isotope composition of 02:

767 Implications for the net-to-gross primary production ratios, Geophysical Research

768 Letters, 38, DOI: 10.1029/2011GL047652.

769 Quay, P. D., J. Stutsman, and T. Steinhoff (2012), Primary production and carbon export

770 rates across teh subpolar N. Atlantic Ocean basin based on triple oxygen isotope and

771 dissolved 02 and Ar gas measurements, Global Biogeochemical Cycles, 26, doi:

$772 \quad 10.1029 / 2010 G B 004003$.

773 Reuer, M. K., B. B. Barnett, M. L. Bender, P. G. Falkowski, and M. B. Hendricks (2007), New

774 Estimates of Southern Ocean Biological Production Rates from $\mathrm{O}_{2} /$ Ar Ratios and the

775 Triple Isotope Composition of $\mathrm{O}_{2}$ Deep-Sea Research Part I, 54, 951-974.

776 Richardson, T. L., and G. A. Jackson (2007), Small Phytoplankton and Carbon Export from

777 the Surface Ocean, Science, 315, 838 - 840, DOI: 810.1126/science.1133471.

778 Rigual-Hernández, A. S., T. W. Trull, S. G. Bray, A. Cortina, and L. K. A. Armand (2015),

779 Latitudinal and temporal distributions of diatom populations in the pelagic waters of

780 the Subantarctic and Polar Frontal zones of the Southern Ocean and their role in the

781 biological pump, Biogeosciences, 12, 5309-5337.

782 Rintoul, S. R., and J. L. Bullister (1999), A late winter hydrographic section from Tasmania

783 to Antarctica, Deep-Sea Rearch I, 46, 1417-1454.

784 Rintoul, S. R., and T. W. Trull (2001a), Seasonal evolution of the mixed layer in the

785 Subanarctic Zone south of Australia, Journal of Geophysical Research-Oceans, 106,

$786 \quad 31447-31462$.

787 Rintoul, S. R., and T. W. Trull (2001b), Seasonal evolution of the mixed layer in the

788 Subantarctic Zone south of Australia, Journal of Geophysical Research-Oceans, 106(C12),

$789 \quad 31447-31462$. 
790 Rintoul, S. R., J. R. Donguy, and D. H. Roemmich (1997), Seasonal evolution of upper ocean 791 thermal structure between Tasmania and Antarctica, Deep-Sea Research, 44(7), 11857921202.

793 Rubin, S. I. (2003), Carbon and nutrient cycling in the upper water column across the Polar 794 Frontal Zone and Antarctic Circumpolar Current along $170^{\circ} \mathrm{W}$, Global Biogeochemical $795 \quad$ Cycles, 17(3), 1087.

796 Ryan-Keogh, T. J., A. I. Macey, M. V. Nirldfoyyit, M. I. Lucas, S. S. Steigenberger, M. C.

797 Stinchcombe, E. P. Achterberg, T. S. Bibby, and C. M. Moore (2013), Spatial and temporal 798 development of phytoplankton iron stress in relation to bloom dynamics in the high799 latitude North Atlantic Ocean, Limnology and Oceanography, 58, 2013.

800 Sarmiento, J. L., and J. C. Orr (1991), Three-dimensional simulations of the impact of 801 Southern Ocean nutrient depletion on atmospheric $\mathrm{CO}_{2}$ and ocean chemistry, Limnology 802 and Oceanography, 36, 1928-1950.

803 Sarmiento, J. L., N. Gruber, M. A. Brzezinski, and J. P. Dunne (2004), High-latitude controls of 804 thermocline nutrients and low latitude biological productivity, Nature, 427, 56-60.

805 Sedwick, P. N., A. R. Bowie, and T. W. Trull (2008), Dissolved iron in the Australian sector of 806 the Southern Ocean (CLIVAR SR3 section): Meridional and seasonal trends, Deep-Sea $807 \quad$ Research I, 55(8), 911-925.

808 Sedwick, P. N., G. R. DiTullio, D. A. Hutchins, P. W. Boyd, F. B. Griffiths, A. C. Crossley, T. W. 809 Trull, and B. Queguiner (1999), Limitation of algal growth by iron deficiency in the 810 Australian Subantarctic region, Geophysical Research Letters, 26(18), 2865-2868.

811 Shadwick, E. H., B. Tilbrook, N. Cassar, T. W. Trull, and S. R. Rintoul (2015a), Summertime 812 physical and biological controls on 02 and $\mathrm{CO} 2$ in the Australian Sector of the Southern 813 Ocean, Journal of Marine Systems, 147, 21-28.

814 Shadwick, E. H., T. W. Trull, B. Tilbrook, A. J. Sutton, E. Schulz, and C. L. Sabine (2015b), 815 Seasonality of biological and physical controls on surface ocean CO2 from hourly 
816 observations at the Southern Ocean Time Series site south of Australia, Global

817 Biogeochemical Cycles, 2014GB004906, 004901-004916.

818 Sigman, D. M., and E. A. Boyle (2000), Glacial/Interglacial variations in atmospheric carbon

819 dioxide, Nature, 407, 859-869.

820 Smith Jr, W. O., R. F. Anderson, J. Keith Moore, L. A. Codispoti, and J. M. Morrison (2000),

821 The US Southern Ocean Joint Global Ocean Flux Study: an introduction to AESOPS, Deep

822 Sea Research Part II: Topical Studies in Oceanography, 47(15-16), 3073-3093.

823 Smith, W. O., and C. Lancelot (2004), Bottom-up versus top-down control in phytoplankton 824 of the Southern Ocean, Antarctic science, 16(04), 531-539.

825 Sokolov, S. (2008), Chlorophyll blooms in the Antarctic Zone south of Australia and New

826 Zealand in reference to the Antarctic Circumpolar Current fronts and sea ice forcing,

827 Journal of Geophysical Research: Oceans, 113(C3), C03022.

828 Sokolov, S., and S. R. Rintoul (2002), Structure of Southern Ocean fronts at 140E, Journal of 829 Marine Systems, 37(1-3), 151-184.

830 Sokolov, S., and S. R. Rintoul (2009), Circumpolar structure and distribution of the Antarctic

831 Circumpolar Current fronts: 1. Mean circumpolar paths, Journal of geophysical research, $832114(\mathrm{C} 11), \mathrm{C} 11018$.

833 Sosik, H. M., and R. J. Olson (2002), Phytoplankton and iron limitation of photosynthetic

834 efficiency in the Southern Ocean during late summer, Deep-Sea Research Part II, 49, $835 \quad 1195-1216$.

836 Steinberg, D. K., B. A. Van Mooy, K. O. Buesseler, P. W. Boyd, T. Kobari, and D. M. Karl

837 (2008), Bacterial vs. zooplankton control of sinking particle flux in the ocean's twilight 838 zone, Limnology and Oceanography, 53(4), 1327-1338.

839 Strzepek, R. F., K. A. Hunter, R. D. Frew, P. J. Harrison, and P. W. Boyd (2012), Iron-light 840 interactions differ in Southern Ocean phytoplankton, Limnology and oceanography, $841 \quad 57(4), 1182-1200$. 
842 Sunda, W. G., and S. A. Huntsman (1997), Interrelated influence of iron, light and cell size on 843 marine phytoplankton growth, Nature, 390, 389-392.

844 Szeto, M., P. J. Werdell, T. S. Moore, and J. W. Campbell (2011), Are the world's oceans 845 optically different?, Journal of Geophysical Research, 116, doi: 10.1029/2011JC007230.

846 Takeda, S. (1998), Influence of iron availability on nutrient consumption ratio of diatoms in 847 oceanic waters, Nature, 393(6687), 774-777.

848 Treguer, P., and G. Jacques (1992), Dynamics of nutrients and phytoplankton, and fluxes of 849 carbon, nitrogen, and silicon in the Antarctic ocean, Polar Biology, 12, 149-162.

850 Trull, T. W., S. R. Rintoul, M. Hadfield, and E. R. Abraham (2001a), Circulation and seasonal 851 evolution of polar waters south of Australia: Implications for iron fertilization of the 852 Southern Ocean, Deep-Sea Research Part Ii-Topical Studies in Oceanography, 48(11-12), $853 \quad 2439-2466$.

854 Trull, T. W., P. N. Sedwick, F. B. Griffiths, and S. R. Rintoul (2001b), Introduction to special 855 section: SAZ Project, Journal of Geophysical Research-Oceans, 106(C12), 31425-31429.

856 Trull, T. W., S. G. Bray, S. J. Manganini, S. Honjo, and R. François (2001c), Moored sediment 857 trap measurements of carbon export in the Subantarctic and Polar Frontal Zones of the 858 Southern Ocean, south of Australia, Journal of Geophysical Research, 106(C12), 3148985931510.

860 Wang, X., and R. J. Matear (2001), Modeling the upper ocean dynamics in the Subantarctic 861 and Polar Frontal Zones in the Australian sector of the Southern Ocean, Journal of $862 \quad$ Geophysical Research, 106(C12), 31511-31524.

863 Wang, X., R. J. Matear, and T. W. Trull (2001), Modeling seasonal phosphate export and 864 resupply in the Subantarctic and Polar Frontal Zones in the Australian sector of the 865 Southern Ocean, Journal of Geophysical Research, 106(C12), 31525-31542.

866 Weeding, B., and T. W. Trull (2014a), Hourly oxygen and total gas tension measurements at 867 the Southern Ocean Time Series site reveal winter ventilation and spring net 868 community production, Journal of Geophysical Research: Oceans, 119(1), 348-358. 
869 Weeding, B., and T. W. Trull (2014b), Hourly oxygen and total gas tension measurements at 870 the Southern Ocean Time Series site reveal winter ventilation and spring net

871 community production, Journal of Geophysical Research - Oceans, 119, 348-358,

872 doi:310.1002/2013JC009302, 002014.

873 Westwood, K. J., F. B. Griffiths, J. P. Webb, and S. W. Wright (2011), Primary production in

874 the Sub-Antarctic and Polar Frontal Zones south of Tasmania, Australia; SAZ-Sense

875 survey, 2007, Deep-Sea Research II, 58, 2162-2178.

876

877

878 


\section{Figures}

Fig. 1. Map of the study region showing the location of each water sample.

Fig. 2. $\left[\mathrm{SiO}_{2}\right]$ and $\left[\mathrm{NO}_{3}{ }^{-}\right]$vs. latitude south of Tasmania during the summer half-years of

884 is February/March. Also plotted is $\left[\mathrm{NO}_{3}{ }^{-}\right]$vs. salinity.

885 Fig. 3. Hovmoller diagrams showing net $\mathrm{O}_{2}$ bioflux (sea-air biological $\mathrm{O}_{2}$ flux, $\mathrm{mmol} \mathrm{m} \mathrm{m}^{-2}$

886 day $\left.^{-1}\right)$, MLD, surface PAR, chlorophyll concentration on a log scale ( $\left.\mu \mathrm{g} / \mathrm{L}\right)$, euphotic depth,

$887 \log (\mathrm{chl})$, and depth-averaged PAR vs. time for a longitude band of $\sim 30$ degrees south of

888 Australia.

Fig. 4. Left: Net and gross bioflux vs. latitude for all samples. Right: Chlorophyll-normalized net and gross bioflux vs. latitude for all samples. Error bars correspond to standard errors. Upper part of the plot shows the number of samples for each degree of latitude.

Fig. 5. Average net (blue) or gross (green) $\mathrm{O}_{2}$ bioflux vs. month of observation for the entire 893 domain.

894 Fig. 6. Net (left) and gross (right) $\mathrm{O}_{2}$ volumetric bioflux normalized to chlorophyll, plotted 895 vs. average mixed layer irradiance.

Fig. 7. Relative production vs. average daily irradiance in the mixed layer. Production is

898 constant at higher irradiances. This plot shows that daily production increases linearly with

899 average mixed layer irradiance up to irradiance values much higher than the instantaneous

900 saturating irradiance, $3.2 \mathrm{~mol} \mathrm{~m}^{-2}$ day $^{-1}$. The reason is that irradiance early in the day, late in the 901 day, and lower in the mixed layer can be undersaturated even when average daily ML irradiance 902 is much greater than the instantaneous saturating value. 


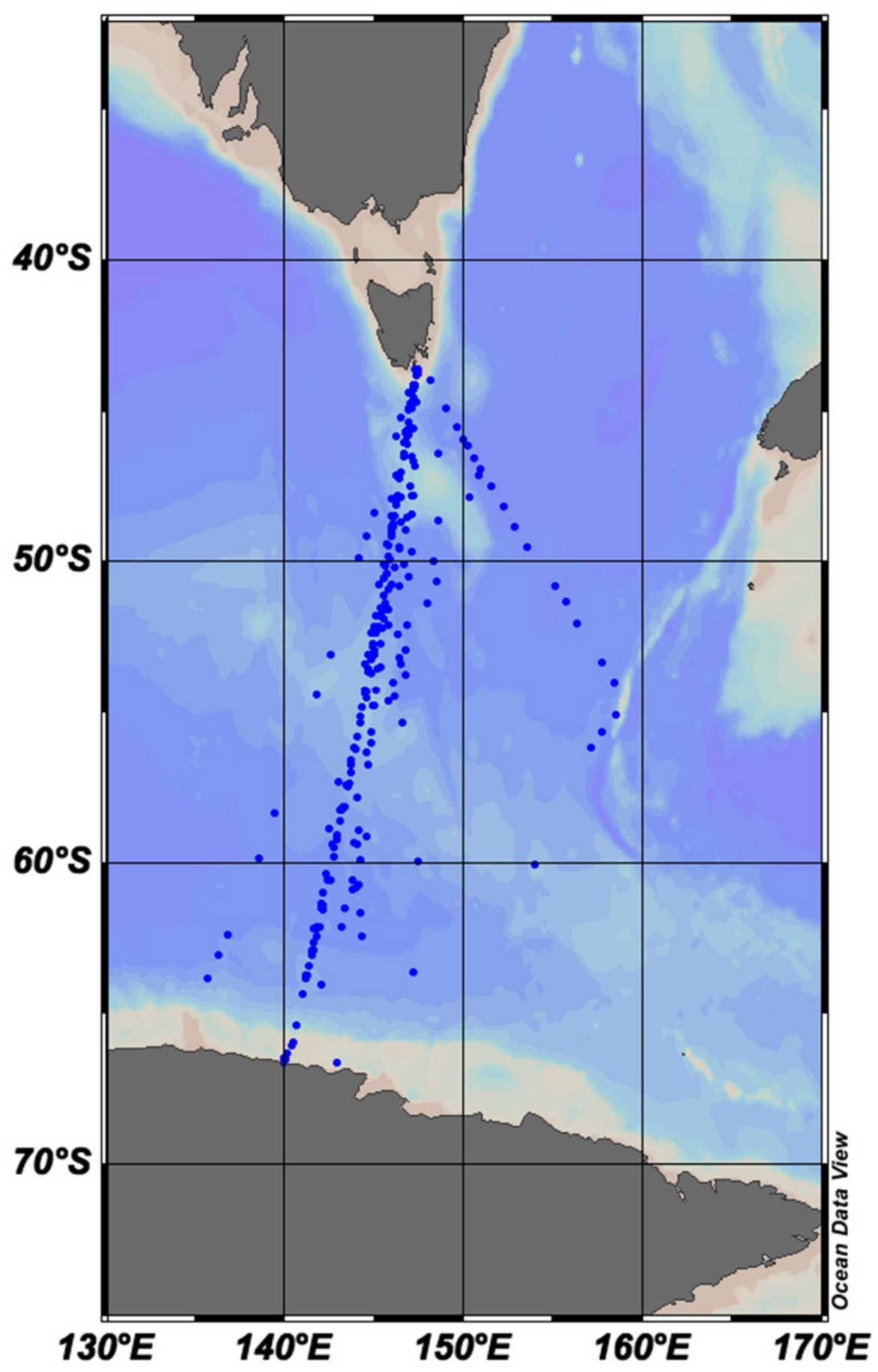

Fig. 1. Map of the study region showing the location of each water sample. 
Fig. 2. $\left[\mathrm{SiO}_{2}\right]$ and $\left[\mathrm{NO}_{3}{ }^{-}\right]$vs. latitude south of Tasmania during the summer halfyears of 2006-2007 (top) and 2007-2008 (bottom). Red is October/November, green is January, and blue is February/March. Also plotted is $\left[\mathrm{NO}_{3}^{-}\right]$vs. salinity.
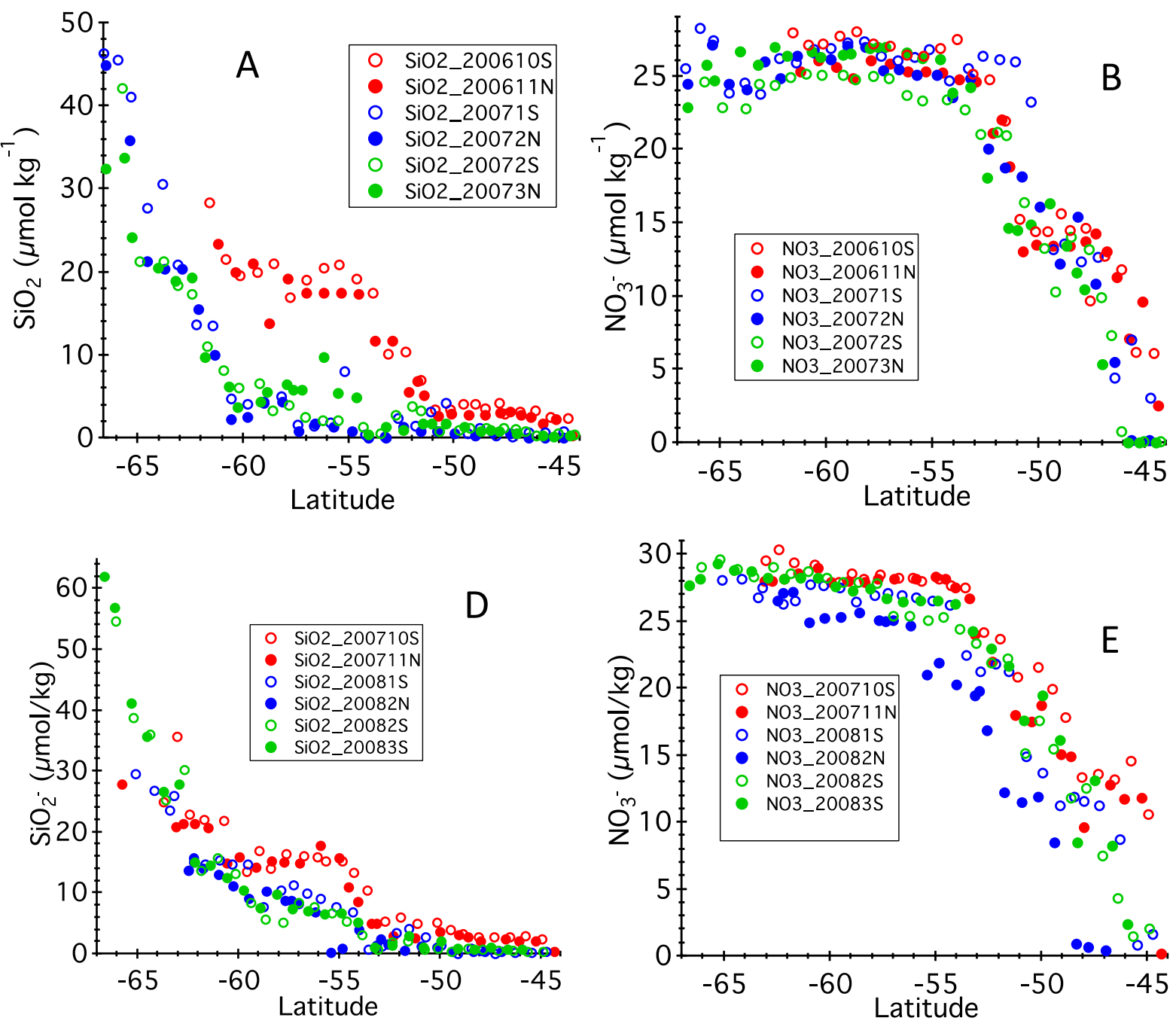
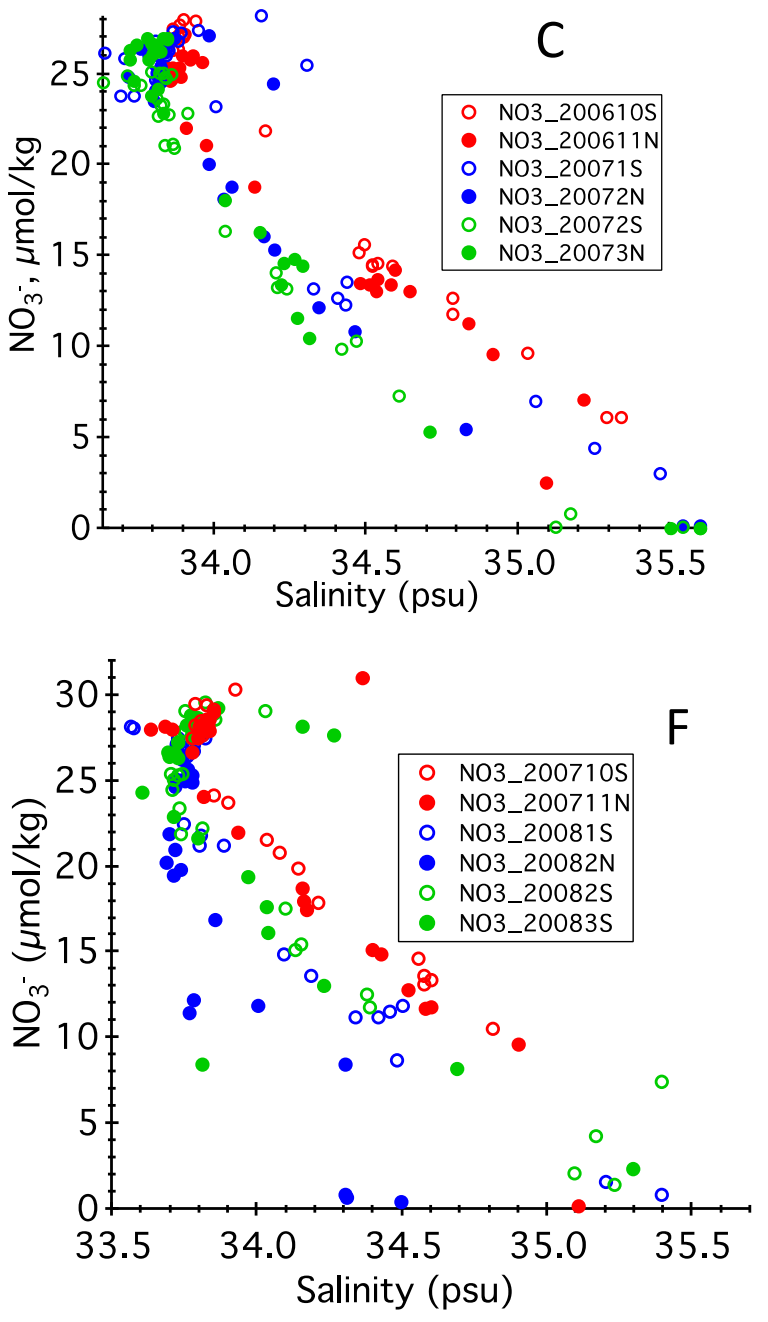
Fig. 3. Hovmoller diagrams showing net $\mathrm{O}_{2}$ bioflux (sea-air biological $\mathrm{O}_{2}$ flux, $\mathrm{mmol} \mathrm{m} \mathrm{m}^{-2}$ day $^{-1}$ ), $\mathrm{MLD}$, surface PAR, chlorophyll concentration on a log scale $(\mu \mathrm{g} / \mathrm{L})$, euphotic depth, $\log (\mathrm{chl})$, and depth-averaged PAR vs. time for a longitude band of $\sim 30$ degrees south of Australia. Chl concentrations are from remote sensing, and MLD is from Argo floats.
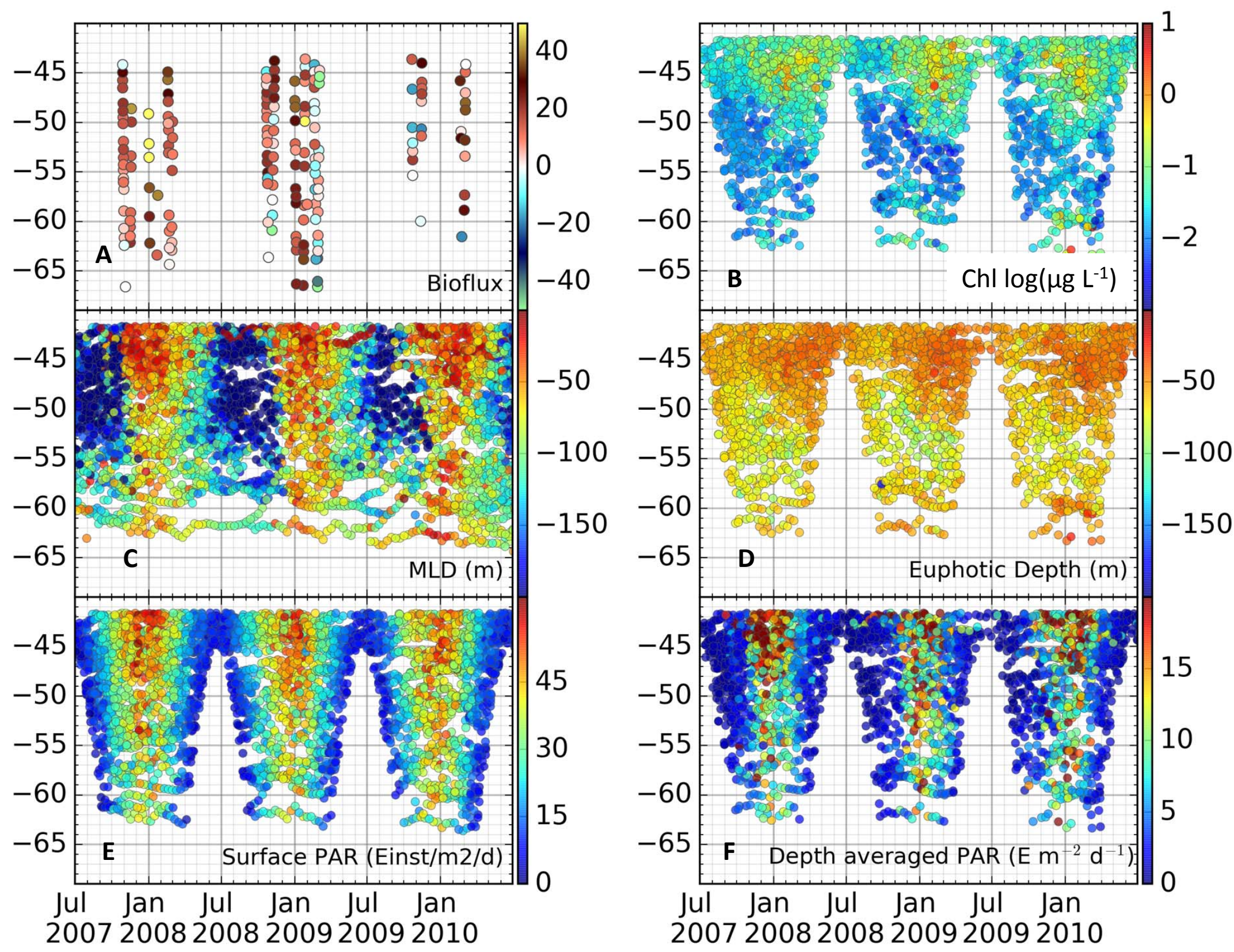
Fig. 4. Left: Net and gross bioflux vs. latitude for all samples. Right: Chlorophyll-normalized net and gross production vs. latitude for all samples. Error bars correspond to standard errors. Upper part of the plot shows the number of samples for each degree of latitude.
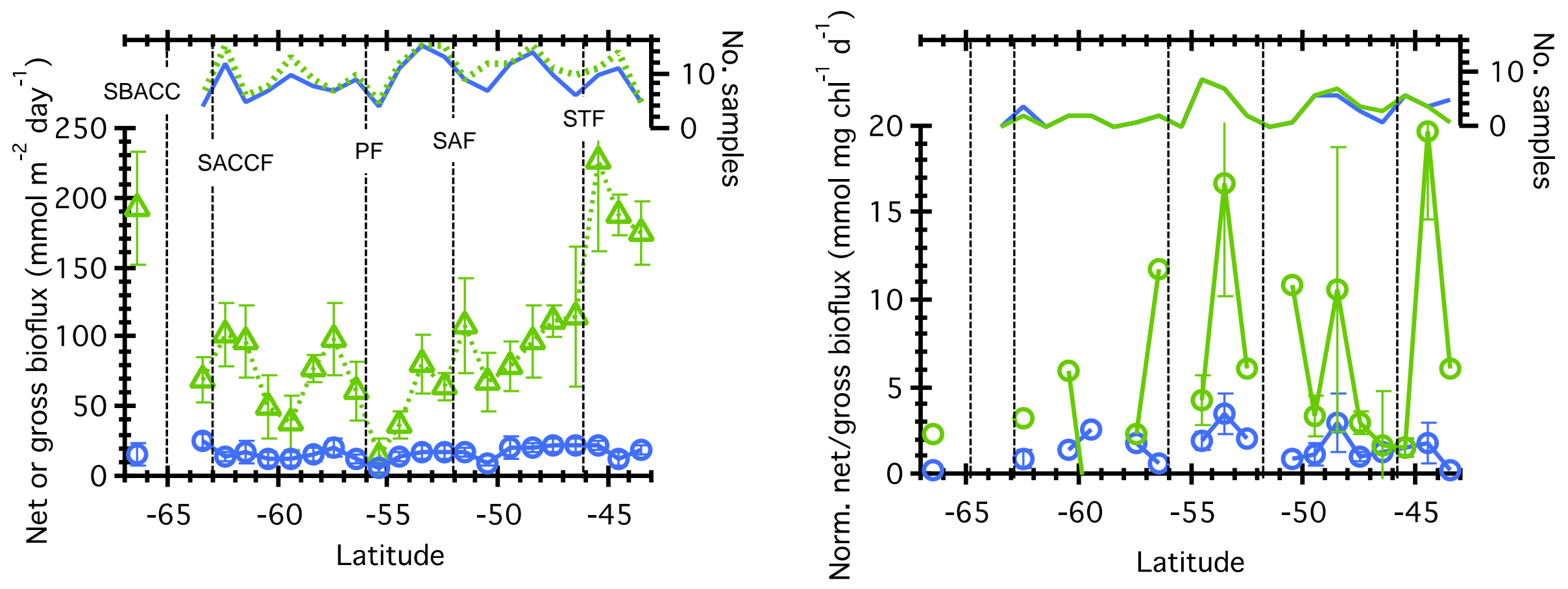
Fig. 5. Average net and gross bioflux for the major zones of the Southern Ocean south of Australia as a function of the month of sampling. STZ, Subtropical Zone (north of $46^{\circ} \mathrm{S}$ ), SAZ, Subantarctic Zone $\left(52^{\circ}-46^{\circ}\right.$ S); PFZ, Polar Frontal Zone $\left(56^{\circ}-52^{\circ} \mathrm{S}\right)$; AZ, Antarctic Zone $\left(63^{\circ}-56^{\circ} \mathrm{S}\right)$, and SACC, South of the Antarctic Circumpolar Current $\left(\mathrm{S}\right.$ of $\left.63^{\circ} \mathrm{S}\right)$.
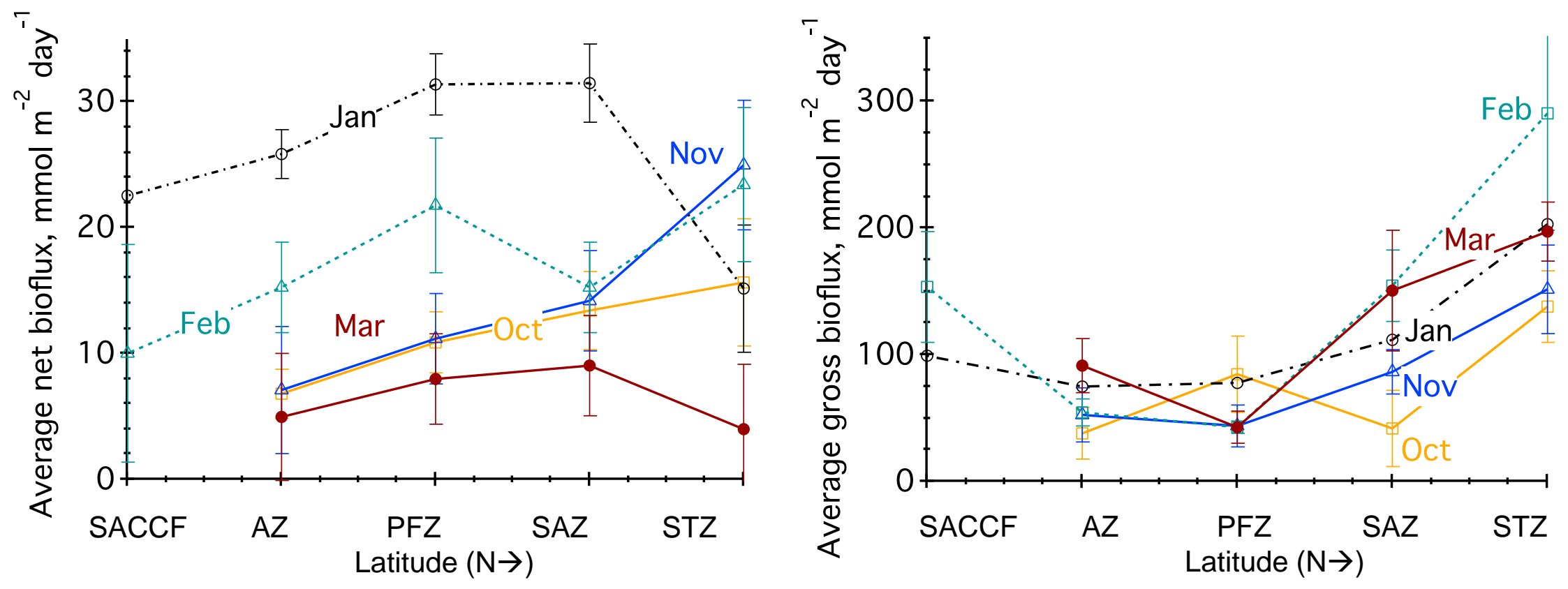
Fig. 6. Net (left) and gross (right) $\mathrm{O}_{2}$ volumetric bioflux normalized to chlorophyll, plotted vs. average mixed layer irradiance. Net and gross $\mathrm{O}_{2}$ bioflux are calculated from mixed layer data and approximate $\mathrm{O}_{2} \mathrm{NCP}$ and $\mathrm{O}_{2} \mathrm{GPP}$ in the mixed layer. Normalized net bioflux is plotted only for samples where the biological $\mathrm{O}_{2}$ supersaturation is $>-0.3 \%$ (within uncertainty of zero).
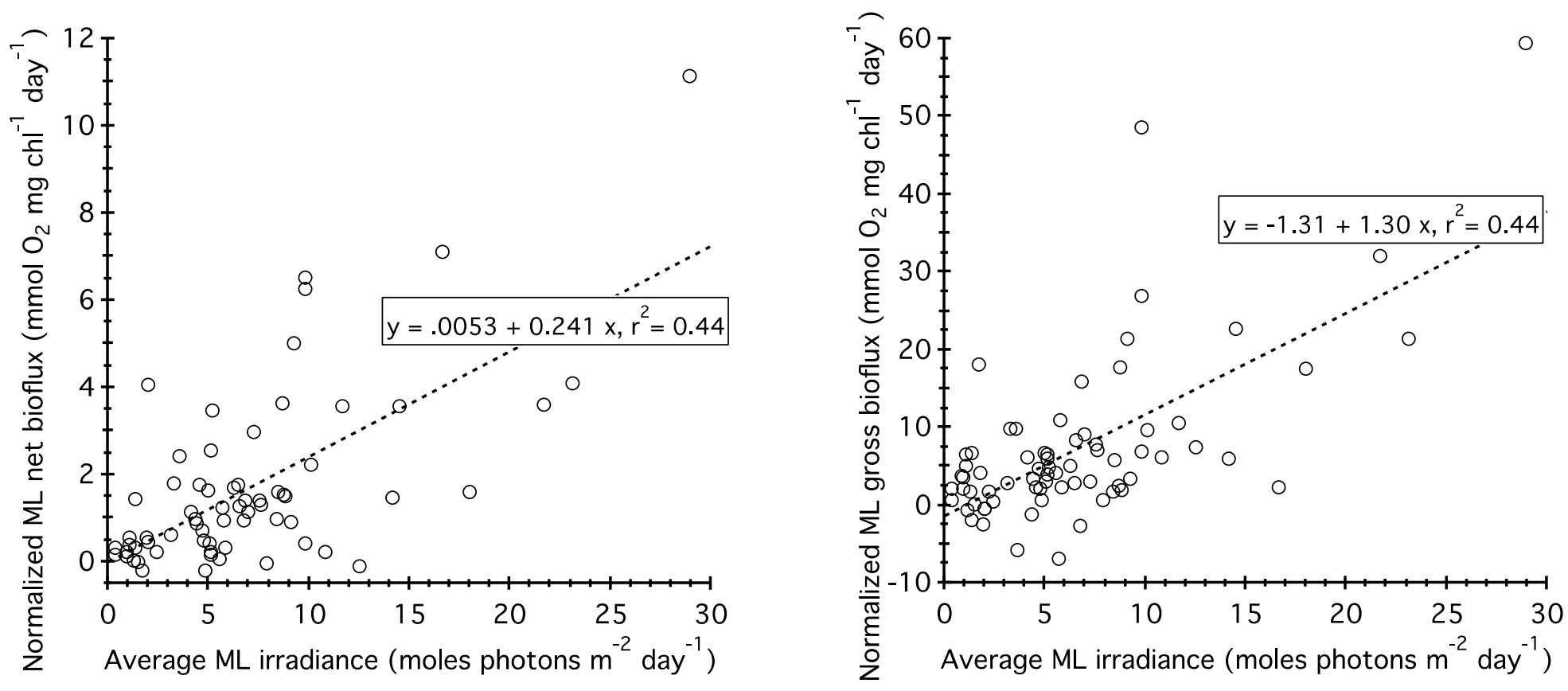
Fig. 7. Relative production vs. average daily irradiance in the mixed layer. Production is assumed to increase linearly up to saturating irradiance (taken as $56 \mu$ moles photons $\mathrm{m}^{-2} \mathrm{sec}^{-1}$ ), and constant at higher irradiances. This plot shows that daily production increases linearly with average mixed layer irradiance up to irradiance values much higher than the instantaneous saturating irradiance, 3.2 moles $\mathrm{m}^{-2} \mathrm{day}^{-1}$. The reason is that irradiance early in the day, late in the day, and lower in the mixed layer can be undersaturated even when average daily ML irradiance is much greater than the instantaneous saturating value.

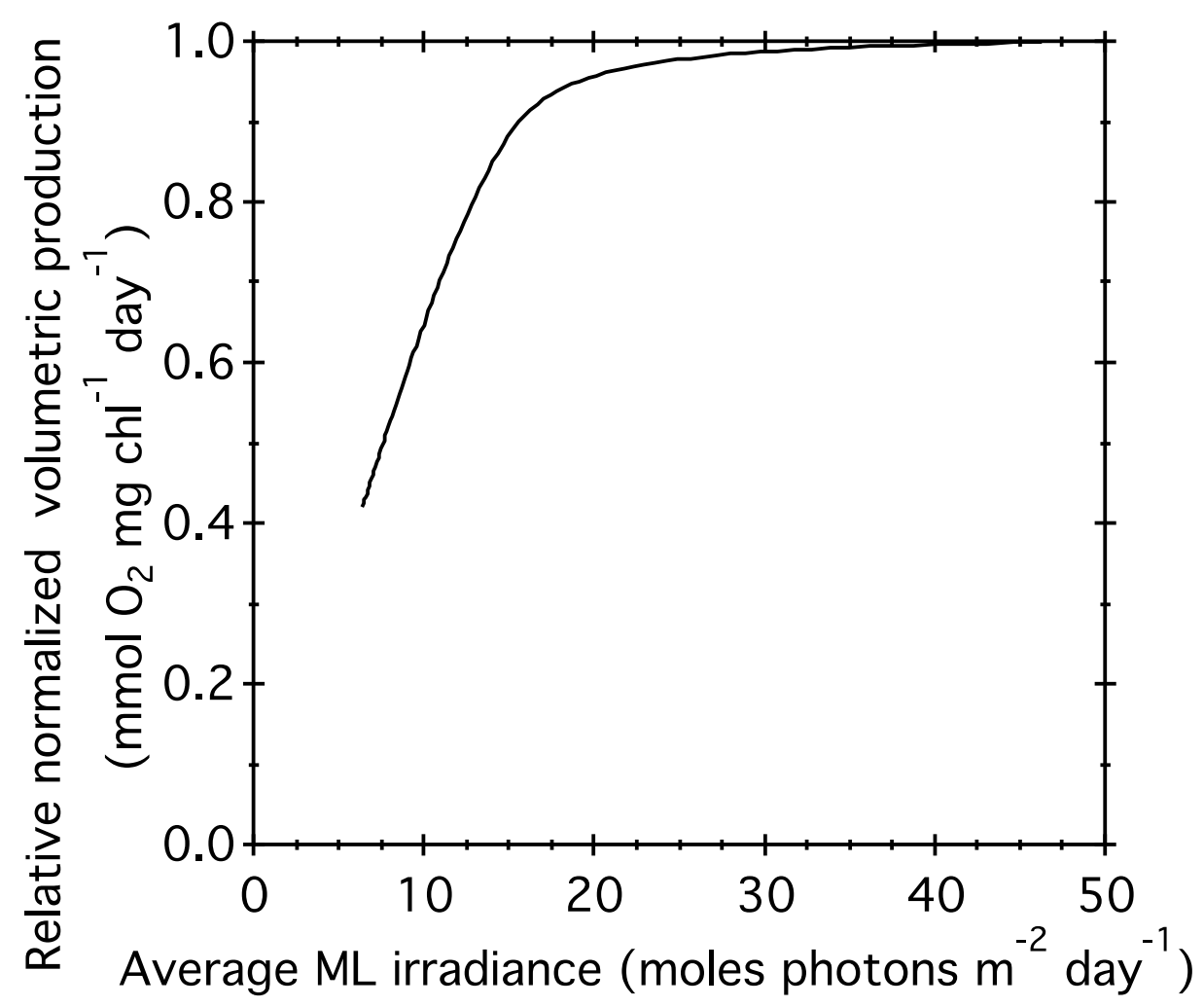

